\title{
Juvenile root vigour improves phosphorus use efficiency of potato
}

Article

Accepted Version

White, P. J., Bradshaw, J. E., Brown, L. K., Dale, M. F. B., Dupuy, L. X., George, T. S., Hammond, J. P., Subramanian, N. K., Thompson, J. A., Wishart, J. and Wright, G. (2018) Juvenile root vigour improves phosphorus use efficiency of potato. Plant and Soil, 432 (1-2). pp. 45-63. ISSN 0032-079X doi: https://doi.org/10.1007/s11104-018-3776-5 Available at https://centaur.reading.ac.uk/79503/

It is advisable to refer to the publisher's version if you intend to cite from the work. See Guidance on citing.

To link to this article DOI: http://dx.doi.org/10.1007/s11104-018-3776-5

Publisher: Springer

All outputs in CentAUR are protected by Intellectual Property Rights law, including copyright law. Copyright and IPR is retained by the creators or other copyright holders. Terms and conditions for use of this material are defined in the End User Agreement.

\section{www.reading.ac.uk/centaur}

\section{CentAUR}


Central Archive at the University of Reading

Reading's research outputs online 
1 Juvenile Root Vigour Improves Phosphorus Use Efficiency of Potato

2

3 Philip J. White ${ }^{1,2}$, John E. Bradshaw ${ }^{1}$, Lawrie K. Brown ${ }^{1}$, M. Finlay B. Dale ${ }^{1}$, Lionel X. Dupuy ${ }^{1}$, Timothy

4 S. George ${ }^{1}$, John P. Hammond ${ }^{3}$, Nithya K. Subramanian ${ }^{1 *}$, Jacqueline A. Thompson ${ }^{1}$, Jane Wishart ${ }^{4}$, 5 Gladys Wright ${ }^{1}$

$8{ }^{1}$ The James Hutton Institute, Invergowrie, Dundee DD2 5DA, UK (philip.white@hutton.ac.uk;

9 johnbradshaw949@btinternet.com; lawrie.brown@hutton.ac.uk; finlaydale@caithnesspotatoes.com;

10 lionel.dupuy@hutton.ac.uk; $\quad$ tim.george@hutton.ac.uk; $\quad \underline{\text { nithya@tamu.edu; }}$

11 jacqueline.thompson@hutton.ac.uk; gladys.wright@hutton.ac.uk)

12

13 2Distinguished Scientist Fellowship Program, King Saud University, Riyadh 11451, Saudi Arabia.

14

$15 \quad{ }^{3}$ School of Agriculture, Policy and Development, University of Reading, Whiteknights

16 PO Box 237, Reading RG6 6AR, UK (j.p.hammond@reading.ac.uk)

17

$18{ }^{4}$ School of Biology, University of St Andrews, St Andrews KY16 9TS, UK (jw211@ @t-andrews.ac.uk)

19

20 *Present address: Soil and Crop Sciences Department, Texas A\&M University, College Station, TX-

2177843 , USA

22

23

26 Address: The James Hutton Institute, Invergowrie, Dundee DD2 5DA, United Kingdom

27 Telephone: +44 (0) 1382560043

28 Fax: 44 (0) 8449285429

29 e-mail: philip.white@ hutton.ac.uk

30 


\section{Abstract}

34 Aims Potato (Solanum tuberosum L.) has a large phosphorus (P)-fertiliser requirement. This is thought to be 35 due to its inability to acquire P effectively from the soil. This work tested the hypothesis that early 36 proliferation of its root system would enhance $\mathrm{P}$ acquisition, accelerate canopy development, and enable 37 greater yields.

39 Methods Six years of field experiments characterised the relationships between (1) leaf P concentration 40 ([P $]_{\text {leaf }}$ ), tuber yield, and tuber P concentration ([P $]_{\text {tuber }}$ ) among 27 Tuberosum, 35 Phureja and 4 Diploid 41 Hybrid genotypes and (2) juvenile root vigour, $\mathrm{P}$ acquisition and tuber yield among eight Tuberosum 42 genotypes selected for contrasting responses to P-fertiliser.

44 Results Substantial genetic variation was observed in tuber yield, $[\mathrm{P}]_{\text {leaf }}$ and $[\mathrm{P}]_{\text {tuber. }}$ There was a strong 45 positive relationship between tuber yields and $\mathrm{P}$ acquisition among genotypes, whether grown with or 46 without P-fertiliser. Juvenile root vigour was correlated with accelerated canopy development and both 47 greater $\mathrm{P}$ acquisition and tuber biomass accumulation early in the season. However, the latter relationships 48 became weaker during the season.

50 Conclusions Increased juvenile root vigour accelerated P acquisition and initial canopy cover and, thereby, 51 increased tuber yields. Juvenile root vigour is a heritable trait and can be selected to improve P-fertiliser use 52 efficiency of potato.

55 Keywords Phosphorus - potato (Solanum tuberosum L.) - root morphology - tuber yield 
Introduction

60 A disproportionately large amount of phosphorus (P)-fertiliser is applied to potatoes (Solanum tuberosum

61 L.) compared to other field crops (Fixen and Bruulsema 2014; Hopkins et al. 2014; Ruark et al. 2014;

62 White et al. 2005b, 2007). For example, in 2016 potatoes occupied 3.0\% of the arable land in Great Britain

63 but consumed $>12 \%$ of all the inorganic P-fertiliser applied to tillage crops (Defra 2017). As a

64 consequence, the potato crop is associated with high P-losses from fields and, consequently, environmental 65 pollution (Dampney et al. 2002; Davenport et al. 2005; Ruark et al. 2014).

The large P-fertiliser requirement of potatoes is thought to be due to their inability to acquire $\mathrm{P}$ effectively from the soil (Dampney et al. 2002; Fageria et al. 2011; Fixen and Bruulsema 2014; Hopkins et al. 2014; Syers et al. 2008; Thornton et al. 2014; White 2018; White et al. 2005b). The potato crop generally recovers $<10 \%$ of broadcast $\mathrm{P}$ fertiliser in the year it is applied (Dampney et al. 2002; Fernandes and Soratto 2016a; Syers et al. 2008) and, although the application of research to optimise the timing, quantities, and methods of P-fertiliser application can reduce inputs of P-fertiliser and P-losses to the environment (e.g. Burns et al. 2010; Davenport et al. 2005; Hopkins et al. 2014; Syers et al. 2008; White 2018; White et al. 2007), the impact of agronomic methods alone to reduce the amount of P-fertiliser applied to the potato crop has been limited (Defra 2017). To reduce P-fertiliser inputs and environmental pollution further requires the development of potato varieties that use P-fertiliser inputs more effectively to produce commercial yields. However, there has been little effort to develop new potato varieties that use Pfertiliser inputs more efficiently (Thornton et al. 2014; Trehan and Sharma 2005; White et al. 2005b).

Agronomic phosphorus use efficiency (PUE) is commonly defined as crop dry matter (DW) yield per unit of P available in the soil ( $\mathrm{g} \mathrm{DW} \mathrm{g}^{-1} \mathrm{P}_{\text {soil }}$; Fernandes and Soratto 2016a; Sandaña 2016; White et al. 2005a). This is numerically equal to the product of $\mathrm{P}$ acquisition efficiency (PUpE), which is defined as the $\mathrm{P}$ acquired by the crop per unit of available $\mathrm{P}\left(\mathrm{g}_{\text {crop }} \mathrm{g}^{-1} \mathrm{P}_{\text {soil }}\right)$, and crop physiological utilisation efficiency 82 (PUtE), which is defined as the yield per unit $\mathrm{P}$ acquired by a crop ( $\mathrm{g} \mathrm{DW} \mathrm{g}{ }^{-1} \mathrm{P}_{\text {crop }}$ ). Differences in yield 83 responses to P-fertiliser applications between crop genotypes, including potato, are often correlated with 84 PUpE, but rarely correlated with PUtE (Balemi and Schenk 2009; Fernandes and Soratto 2016a; Sandaña 85 2016; Soratto et al. 2015; Thornton et al. 2014; Trehan and Sharma 2005; White 2018; White and 86 Hammond 2008; White et al. 2005a, 2013). In potato, greater PUpE has been attributed to increased biomass allocation to roots, greater exploitation of the soil volume through the production of more lateral roots, longer root hairs and roots with a greater length/mass ratio, topsoil foraging, and the exudation of organic acids and phosphatases into the rhizosphere (Balemi and Schenk 2009; Dechassa et al. 2003;

90 Fernandes et al. 2014; Opena and Porter 1999; Sattelmacher et al. 1990; Trehan and Sharma 2003, 2005;

91 White 2018; White et al. 2005ab). Simulations of P acquisition by potato plants suggest that PUpE is 92 determined to a large extent by the size and morphology of the root system and, to a lesser extent, by the 93 kinetics of P uptake by root cells (Balemi and Schenk 2009; Dechassa et al. 2003). 
There is limited information on genetic variation in PUE, PUpE or PUtE among commercial potato germplasm (Fernandes and Soratto 2016ab; Hailu et al. 2017; Nyiraneza et al. 2017; Sandaña 2016; Trehan and Singh 2013). However, variation has been observed among genotypes of European potato ( $S$. tuberosum Group Tuberosum) in the following traits:

- Tuber yield (e.g. Allen and Scott 1992; Bradshaw et al. 2008; Daoui et al. 2014; Fernandes and Soratto 2013, 2016ab; Fixen and Bruulsema 2014; Hailu et al. 2017; Lahlou and Ledent 2005; Lee et al. 2013; Manorama et al. 2017; McCord et al. 2011; Nyiraneza et al. 2017; Sandaña 2016; Sandaña and Kalazich 2015; Soratto and Fernandes 2016; Soratto et al. 2015; Trehan and Singh 2013; White et al. 2009)

- Phosphorus acquisition (Balemi 2011; Carpenter 1963; Fernandes and Soratto 2013, 2016a; Fernandes et al. 2014, 2015; Hailu et al. 2017; Nyiraneza et al. 2017; Sandaña 2016; Soratto et al. 2015; Trehan and Sharma 2003, 2005; Trehan and Singh 2013)

- Leaf P concentration (Balemi 2011; Balemi and Schenk 2009; Carpenter 1963; Dampney et al. 2002; Fernandes and Soratto 2016ab; Fernandes et al. 2014, 2015; Kärenlampi and White 2009; Lee et al. 2013; Sandaña 2016; Soratto and Fernandes 2016; Soratto et al. 2015; Trehan and Sharma 2003, 2005)

- Tuber P concentration (Bethke and Jansky 2008; Carpenter 1963; Dampney et al. 2002; Ereifej et al. 1998; Fernandes and Soratto 2016a; Fernandes et al. 2015; Lee et al. 2013; Leonel et al. 2017; Lombardo et al. 2014; Randhawa et al. 1984; Sandaña 2016; Soratto and Fernandes 2016; Tekalign and Hammes 2005; Thornton et al. 2014; Trehan and Sharma 2003; White et al. 2009)

- Tuber yield / crop P accumulation (Fernandes and Soratto 2013; Fernandes et al. 2014; Hailu et al. 2017; Nyiraneza et al. 2017; Sandaña 2016; Trehan and Sharma 2003)

- Tuber yield response to P availability (Daoui et al. 2014; Fernandes and Soratto 2016a; Freeman et al. 1998; Hailu et al. 2017; Jenkins and Ali 1999; Manorama et al. 2017; Nyiraneza et al. 2017; Sandaña 2016; Sandaña and Kalazich 2015; Soratto and Fernandes 2016; Soratto et al. 2015; Thornton et al. 2014; Trehan and Singh 2013)

The effects of $\mathrm{P}$ acquisition on tuber numbers and crop yields are believed to be mediated through canopy development and radiation absorption at tuber initiation, which occurs two to three weeks after shoot emergence in most varieties, and during tuber bulking, respectively (Allison et al. 2001; Dampney et al. 2002; Fernandes et al. 2014; Harris 1992; Haverkort 2007; Jenkins and Ali 1999, 2000; Kolbe and Stephan-Beckmann 1997b; O’Brien et al. 1998; Sandaña and Kalazich 2015; White 2018; White et al. 2005b). Thus, it has been speculated that rapid development of the root system will enhance the ability to acquire P, accelerate canopy development, increase tuber numbers and enable greater yields (White 2018; White et al. 2005b). This is consistent with observations that tuber yield is positively correlated with root dry weight not only among genotypes of $S$. tuberosum Group Tuberosum but also among $S$. tuberosum genotypes sensu lato and other tuber-bearing Solanum species (Iwama 2008; Iwama et al. 1981ab, 1999; Lahlou and Ledent 2005; Sattelmacher et al. 1990; Wishart et al. 2013). 
There is considerable genotypic variation in both root growth and root architecture in potato (Ahmadi et al. 2017; Allen and Scott 1992; Fernandes et al. 2014; Harris 1992; Iwama 1998, 2008; Iwama and Nishibe 1989; Iwama et al. 1981ab, 1999; Jefferies 1993; Kratzke and Palta 1992; Lahlou and Ledent 2005; MacKerron and Peng 1989; Puértolas et al. 2014; Sattelmacher et al. 1990; Stalham and Allen 2001; Steckel and Gray 1979; Trehan and Sharma 2003, 2005; Trehan and Singh 2013; van Loon 1986; White et al. 2005a; Wishart et al. 2013, 2014). Furthermore, genotypic variation in the number, diameter, length, surface area and fresh weight (FW) of basal and stolon roots observed in field-grown plants 10 weeks after planting can also be observed in glasshouse-grown plants two weeks after emergence (Wishart et al. 2013), suggesting that relevant aspects of root architecture can be screened rapidly and cost effectively. Although commercial potato varieties often show little variation in their maximal root growth rates, the eventual depth of rooting differs between varieties because the duration of active root growth varies and is particularly extended in indeterminate varieties (Ahmadi et al. 2017; Allen and Scott 1992; Iwama 1998, 2008; Lahlou and Ledent 2005; Stalham and Allen 2001). For example, Cara, an indeterminate variety with exceedingly long haulm longevity, produces a larger and deeper root system than the indeterminate varieties Maris Piper, Desiree and Hermes, which, in turn, have deeper root systems than the partially determinate varieties Estima and Wilja (Allen and Scott 1992; Harris 1992; Jefferies 1993; Stalham and Allen 2001, Wishart et al. 2009). Thus, there appears to be potential for the selection or breeding of potato genotypes with root systems that exploit the soil volume and acquire P more efficiently.

In this paper, (1) genetic and environmental variation in PUE, PUpE and PUtE is quantified in a collection of commercial germplasm containing S. tuberosum Group Tuberosum, Group Phureja and Diploid Hybrid genotypes, and (2) the relationships between the biomass of the juvenile root system and P

\section{Materials and Methods}

Quantifying variation among potato genotypes in the field

Field trials incorporating tetraploid and diploid Solanum tuberosum genotypes were conducted at Gourdie 159 Farm, Dundee $\left(56^{\circ} 28^{\prime} \mathrm{N}, 03^{\circ} 07^{\prime} \mathrm{W}\right)$, in 2006, 2007 and 2008 (Experiment 1; Table 1). The 23 tetraploid 160 (Solanum tuberosum Group Tuberosum) genotypes included in all three trials were the breeding clone 161 12601ab1, 'Ailsa', 'Anya', 'Brodick', 'Cara', 'Desiree', 'Estima', 'Golden Millennium', 'Hermes', 'Home 162 Guard', 'Harborough Harvest', 'Maris Piper', 'Montrose', 'Nadine', 'Pentland Dell', 'Pentland Squire', 163 'Record', 'Saxon', 'Scarborough', 'Stirling', 'Tay', 'Vales Everest', and 'Wilja'. The varieties 'Eve 164 Balfour', 'Lady Balfour' and 'Vales Sovereign' were included in trials in 2006, and four replicates of 165 'Edzell Blue' were included in trials in 2008. Diploid S. tuberosum Group Phureja genotypes present in all 166 three trials included the six commercial varieties 'Mayan Gold' [DB.337(37)], 'Inca Dawn' [DB.375(1)], 
'Inca Sun' [DB.378(1)], 'Mayan Star' [DB.384(4)], 'Mayan Queen' [DB.520(11)] and 'Mayan Twilight' [PHU.95(1901)] and 29 breeding lines. Group Phureja genotype TC.43(45) was included in trials in 2006 and 2007. Two diploid genotypes, HB.165(1) and HB.171(13), originating from crosses between Diploid Tuberosum and Phureja genotypes were also present in all three trials, whereas the Diploid Tuberosum genotype 2DH40(3) and genotype 99.FT1(5), which originated from a cross between 2DH40(3) and Mayan Gold, were only included in 2007 (Table 1). All husbandry, including fertiliser additions, followed standard UK agronomic practices. Plants were grown in randomized block designs, with eight plants per plot and two replicate plots per genotype. Seed potatoes were planted in late April, diagnostic leaves, defined as youngest fully expanded leaves (Fageria et al. 2011; White 2018; White et al. 2007) were sampled in the second week of July, and tubers were harvested at commercial maturity in September. The fresh weights (FWs) of tubers from each plot were determined at harvest.

Field trials incorporating 23 Tuberosum genotypes, seven Phureja genotypes and two diploid hybrids were performed in Dron Field, Balruddery Farm, Dundee $\left(56^{\circ} 28^{\prime} \mathrm{N}, 03^{\circ} 03^{\prime} \mathrm{W}\right)$, in 2009 and 2010 (Experiment 2; Table 2). The Tuberosum genotypes were the breeding clone 12601ab1, 'Ailsa', 'Anya', 'Brodick', 'Cara', 'Desiree', 'Estima', 'Golden Millennium', 'Hermes', 'Home Guard', 'Harborough Harvest', 'Maris Piper', 'Montrose', 'Nadine', 'Pentland Dell', 'Pentland Squire', 'Record', 'Saxon', 'Scarborough', 'Stirling', 'Tay', 'Vales Everest', and 'Wilja'. The seven phureja genotypes were 'Mayan Gold' [DB.337(37)], 'Inca Dawn' [DB.375(1)], 'Inca Sun' [DB.378(1)], 'Mayan Star' [DB.384(4)], 'Mayan Queen' [DB.520(11)], 'Mayan Twilight' [PHU.95(1901)] and DB.226(70). The two diploid hybrids were 99.FT1(5) and HB.171(13). Two treatments were imposed by the addition, or not, of Pfertiliser at a rate of $147 \mathrm{~kg} \mathrm{ha}^{-1} \mathrm{P}_{2} \mathrm{O}_{5}$ (Defra 2010). Prior to the addition of P-fertiliser, Olsen-P concentrations (Olsen et al. 1954) in the soil were $43 \mathrm{mg} \mathrm{kg}^{-1}$ and $40 \mathrm{mg} \mathrm{kg}^{-1}$ in 2009 and 2010, respectively. All other husbandry followed standard UK agronomic practices. For each P-fertiliser treatment, plants were grown in randomized block designs, with five plants per plot and two replicate plots per genotype. In both years, seed potatoes were planted in the first week of May, diagnostic leaves were sampled in the second week of July, and tubers were harvested at commercial maturity in the first week of September. The FWs of tubers from each plot were determined at harvest.

Relationships between the size of the juvenile root system and crop establishment, canopy development and tuber yield

In 2011, field trials incorporating eight Tuberosum genotypes (Experiment 3) were performed in School Field, Mylnefield Farm, Dundee $\left(56^{\circ} 27^{\prime} \mathrm{N}, 03^{\circ} 03^{\prime} \mathrm{W}\right)$. The genotypes were the breeding clone 12601 ab1, 'Ailsa', 'Cara', 'Home Guard', 'Maris Piper', 'Nadine', 'Pentland Dell' and 'Stirling'. Two treatments were imposed by the addition, or not, of P-fertiliser at a rate of $147 \mathrm{~kg} \mathrm{ha}^{-1} \mathrm{P}_{2} \mathrm{O}_{5}$ (Defra 2010). Prior to the addition of P-fertiliser, the Olsen-P concentration in the soil was $49 \mathrm{mg} \mathrm{kg}^{-1} \mathrm{P}_{2} \mathrm{O}_{5}$. All other husbandry followed standard UK agronomic practices. 
In each P-fertiliser treatment, plants were grown in seven experimental sections with 16 plots per section. Within each section, plants were grown in a randomized block design with two replicate plots per genotype. Sections 1 and 2 contained single plant plots to allow the excavation of juvenile root systems, whilst sections 3 to 7 contained five experimental plants per plot. Guard plots were planted with 'Edzell Blue' on the sides of the experiment, and as single plants, on the edges of sections 3 to 7 to reduce edge effects. The date of emergence was recorded for each plot in each section and photographs were taken fortnightly to estimate percentage ground cover. Sections 1 and 2 were harvested between 29 and 30 June, 2011, approximately three weeks after emergence (Harvest 1). Section 3 was harvested on 14 July, when the canopy had about 50\% ground cover (Harvest 2). Section 4 was harvested on 27 July, close to canopy closure (Harvest 3). Section 5 was harvested on 9 August (Harvest 4). Section 6 was harvested on 23 August, when the canopy had begun to sag (Harvest 5). Section 7 was harvested on 3 October (Harvest 6).

At planting, the seed tuber FW / dry weight (DW) quotient was determined for each variety according to the following procedure. Five representative tubers were washed, dried, and their combined FW determined. The tubers were then cut into eighths and freeze-dried (Millitorr S3921 Vacuum FreezeDrying Unit; Millitorr Engineering Ltd., Manchester, UK). Freeze-dried material was weighed to determine the combined DW of the five representative tubers. Three replicate samples were processed for each variety.

At Harvest 1, individual plants were lifted in situ using a JCB forklift and bucket (JCB, Rochester, UK) and carefully excavated from the soil by a team of people. Plants were then separated into seed tuber, new tuber, root and shoot material. Fresh weights of each plant part were determined immediately. At all other harvests, the shoot of the middle plant of each plot was first removed by excision at the soil surface using secateurs and processed separately. Shoot material from the remaining plants of each plot was then removed, and, finally, tubers from each plot were harvested using a potato harvester (Grimmie, Swineshead, Lincolnshire, UK). The FWs of shoot material from the middle plant and from the other plants in the plot were determined separately. These data were combined to give values for the plot. The FWs of tubers harvested from each plot were determined.

Root and shoot samples from Harvest 1 were oven-dried at $70{ }^{\circ} \mathrm{C}$ for $72 \mathrm{~h}$ and their DWs determined. Whole shoots from the middle plant of each plot from Harvests 2 to 6 were oven-dried at $70{ }^{\circ} \mathrm{C}$ for $72 \mathrm{~h}$ and their DWs determined. These data were combined with data on the FWs of shoot material collected from an entire row to calculate shoot DW for that plot. Tubers from Harvests 2 to 6 were first washed. A minimum of six representative tubers from each plot from Harvest 2 were combined, weighed fresh, chopped and freeze dried. The DW of these representative tubers was used to determine dry matter content. Five representative tubers from each plot of Harvests 3 to 6 were combined, weighed fresh, chopped and a sub-sample of the chopped material of known FW was freeze dried. The DW of these subsamples of representative tubers was used to determine dry matter content.

Estimation of ground covered by the crop canopy 
242 The ground covered by the crop canopy was estimated for each plot according to the following procedure.

243 First a white plastic quadrat (dimensions $40 \times 90 \mathrm{~cm}$ ) was placed over the middle plant of the plot. Then, an

244 image containing the entire quadrat was acquired from a position approximately $2 \mathrm{~m}$ above the ground.

245 Images were analysed semi-automatically using customised scripts executed in ImageJ (Rasband 2014). A

246 binary (black and white) image was obtained from a greyscale image by applying a fixed threshold. The

247 boundaries of white regions in the image were identified using an edge tracing algorithm. Gaussian noise

248 and smoothing was applied to these regions to create local maxima and a convex hull was created around

249 the local maxima to identify the frame of the quadrat. Leaves were then identified from the colour image,

250 which was converted to a grayscale image using the transformation $b^{3} / \max (r) \max (g)$, where $r, g$ and $b$

251 represent the pixel intensities in the red, green and blue channels, respectively. A binary (black and white)

252 image was obtained by applying a fixed threshold and the boundaries of white regions in the image

253 (representing the leaves) were identified using an edge tracing algorithm. The area of leaves was expressed

254 as a percentage of the total area within the quadrat.

255

256

Analysis of tissue phosphorus concentrations

Phosphorus concentrations of root, tuber, leaf and shoot material were determined on acid-digested dried plant material using either inductively-coupled plasma emission spectrometry (ICP-AES; JY Ultima 2; Jobin Yvon Ltd., Stanmore, UK) or inductively-coupled plasma mass spectrometry (ICP-MS; ELAN DRCe; PerkinElmer, Waltham, MA, USA) following published methods (Hammond et al. 2009; Subramanian et al. 2011).

Diagnostic leaves from Experiments 1 and 2 were freeze-dried and their DW determined. Tubers from Experiments 1 and 2 were processed as described by White et al. (2012). Three representative tubers from each plot were washed and cut into eighths by first slicing horizontally from rose-to-heel, then vertically from rose-to-heel, and finally vertically midway between rose and heel. Subsamples from each plot, comprising four diagonally opposite eighths of all representative tubers sampled from that plot, were weighed fresh and freeze-dried. Freeze-dried tuber material was weighed to determine dry matter content. Freeze-dried leaf and tuber material was milled to a powder using a ball-mill. Accurately weighed subsamples (approx. $100 \mathrm{mg} \mathrm{DW}$ ) of each milled sample were digested using the micro-Kjeldahl method and P concentrations were determined using ICP-AES as described by Hammond et al. (2009). Mill; Christy and Norris Ltd., Chelmsford, UK). Phosphorus concentrations in the powdered samples were

274 determined as described by Subramanian et al. (2011). Accurately weighed sub-samples (approx. $50 \mathrm{mg}$ 275 DW) of each milled material were digested with $3.0 \mathrm{ml}$ concentrated nitric acid and $1.0 \mathrm{ml}$ of $30 \%(\mathrm{v} / \mathrm{v})$ 276 hydrogen peroxide in closed vessels using a microwave digester (MARS Xpress; CEM Microwave 277 Technology, Buckingham, UK) with the following programme: $2 \mathrm{~min}$ at $100^{\circ} \mathrm{C}, 1 \mathrm{~min}$ at $120^{\circ} \mathrm{C}, 2 \mathrm{~min}$ at 
$160^{\circ} \mathrm{C}, 20 \mathrm{~min}$ at $180^{\circ} \mathrm{C}$, and $20 \mathrm{~min}$ cooling time. Each digested sample was diluted to $50 \mathrm{ml}$ with sterile MilliQ water $(18.2 \mathrm{M} \Omega \mathrm{cm})$ prior to elemental analyses. Blank digestions were also performed and the National Institute of Standards and Technology (NIST, Gaithersburg, MD, USA) tomato leaf standard (Reference Number 1573a) was used as an internal control. Phosphorus concentrations in digested plant samples were determined using ICP-MS.

\section{Statistical analyses}

Data are expressed as means \pm standard errors from $n$ determinations unless indicated otherwise. The significance of the difference between two sets of data was attributed through the Student's $t$-test. Linear regressions and analysis of variance (ANOVA) were performed using Microsoft Office Excel (Microsoft Corporation, Redmond, WA, USA).

\section{Results}

Genetic and environmental effects on tuber yield, tuber $\mathrm{P}$ concentration and leaf $\mathrm{P}$ concentration

Genetic variation was observed in tuber yield, P-concentration in diagnostic leaves $\left([\mathrm{P}]_{\text {leaf }}\right)$ and $\mathrm{P}$ concentration in tubers $\left([\mathrm{P}]_{\text {tuber }}\right)$ among potato genotypes grown in the field following standard UK agronomic practices (Tables 1, 2). In Experiment 1, the yield of Tuberosum genotypes, averaged across three years for genotypes present in all trials, was greater than that of Diploid Hybrid genotypes or Phureja genotypes (Table 1). The $[\mathrm{P}]_{\text {leaf }}$ of Tuberosum genotypes, averaged across two years for genotypes present in all trials, was less than that of Diploid Hybrid genotypes or Phureja genotypes, but $[\mathrm{P}]_{\text {tuber }}$ of Tuberosum genotypes, averaged across three years for genotypes present in all trials, was similar to that of Diploid Hybrid genotypes and Phureja genotypes (Table 1). The product of yield and $[\mathrm{P}]_{\text {leaf }}$, which can be used as a proxy for PUpE assuming similar partitioning of biomass and P among genotypes (White et al. 2005a), averaged across two years for genotypes present in all trials, was significantly greater for Tuberosum genotypes than Phureja genotypes, because of their higher yields and lower $[\mathrm{P}]_{\text {leaf }}$ (Table 1).

The data obtained in Experiment 2 were consistent with those of Experiment 1. In Experiment 2, the yield of Tuberosum genotypes, averaged across both years, was greater than that of Diploid Hybrid genotypes or Phureja genotypes, whether grown with or without P-fertiliser application, and $[\mathrm{P}]_{\text {leaf }}$ of Tuberosum genotypes, averaged across both years, was similar to that of Diploid Hybrid genotypes and Phureja genotypes, whether grown with or without $\mathrm{P}$-fertiliser application, and $[\mathrm{P}]_{\text {tuber }}$ of Tuberosum genotypes, averaged across both years, was similar to those of Diploid Hybrid genotypes and Phureja genotypes, whether grown with or without P-fertiliser application (Table 2). The product of yield and $[\mathrm{P}]_{\text {leaf }}$ 
314 for genotypes averaged across both years was significantly greater for Tuberosum genotypes than Diploid 315 Hybrid genotypes or Phureja genotypes, whether grown with or without P-fertiliser application (Table 2).

316 According to ANOVA, there were significant effects of both genetic group (Tuberosum, Phureja, 317 Diploid Hybrid) and year on tuber yield in both Experiment 1 ( $\mathrm{P}<0.001, \mathrm{n}=3$ groups; $\mathrm{P}<0.001, \mathrm{n}=3$ years) 318 and Experiment $2(\mathrm{P}<0.001, \mathrm{n}=3$ groups; $\mathrm{P}<0.001, \mathrm{n}=2$ years $)$. However, there was no significant 319 interaction between genetic group and year on tuber yield in Experiment $1(\mathrm{P}=0.504)$ or Experiment 2 320 (0.790). A significant effect of P-fertiliser application on tuber yield was observed in Experiment 2 $321(\mathrm{P}=0.003, \mathrm{n}=2$ treatments), but no significant interactions between $\mathrm{P}$-fertiliser application and year $322(\mathrm{P}=0.077)$, genetic group and $\mathrm{P}$-fertiliser application $(\mathrm{P}=0.712)$, or genetic group, year and $\mathrm{P}$-fertiliser 323 application $(\mathrm{P}=0.575)$ on tuber yield were apparent. Similarly, there were significant effects of both genetic 324 group and year on $[\mathrm{P}]_{\text {leaf }}$ in both Experiment $1(\mathrm{P}<0.001, \mathrm{n}=3$ groups; $\mathrm{P}<0.001, \mathrm{n}=2$ years $)$ and Experiment $3252(\mathrm{P}=0.014, \mathrm{n}=3$ groups; $\mathrm{P}<0.001, \mathrm{n}=2$ years). A significant interaction between genetic group and year on $326[\mathrm{P}]_{\text {leaf }}$ was observed in Experiment $1(\mathrm{P}<0.001)$, but not in Experiment $2(\mathrm{P}=0.576)$. No effect of $\mathrm{P}$-fertiliser 327 application on $[\mathrm{P}]_{\text {leaf }}$ was observed in Experiment $2(\mathrm{P}=0.221)$ and no significant interactions between $\mathrm{P}$ 328 fertiliser application and year $(\mathrm{P}=0.590)$, genetic group and $\mathrm{P}$-fertiliser application $(\mathrm{P}=0.550)$ or genetic 329 group, year and $\mathrm{P}$-fertiliser application $(\mathrm{P}=0.147)$ were apparent. For the product of yield and $[\mathrm{P}]_{\text {leaf }}$ (as a 330 proxy for $\mathrm{PUpE})$, there were significant effects of both genetic group and year in Experiment $1(\mathrm{P}<0.001$, $331 \mathrm{n}=3$ groups; $\mathrm{P}<0.001, \mathrm{n}=2$ years), but only effects of genetic group $(\mathrm{P}<0.001, \mathrm{n}=3$ groups) and not year $332(\mathrm{P}=0.670)$ in Experiment 2. There was a significant interaction between genetic group and year on $\mathrm{PUpE}$ in 333 Experiment $1(\mathrm{P}=0.002)$, but not in Experiment $2(\mathrm{P}=0.697)$. An effect of P-fertiliser application on PUtE 334 was observed in Experiment $2(\mathrm{P}=0.006)$, but no significant interactions between fertiliser application and 335 year $(\mathrm{P}=0.129)$, genetic group and $\mathrm{P}$-fertiliser application $(\mathrm{P}=0.889)$ or genetic group, year and $\mathrm{P}$-fertiliser 336 application $(\mathrm{P}=0.636)$ interactions were apparent.

337 There was a strong positive linear relationship between tuber yield when grown without P338 fertiliser application and tuber yield when grown with P-fertiliser application among genotypes (Fig. 1A) in 339 both $2009\left(\mathrm{R}^{2}=0.8836, \mathrm{P}<0.0001, \mathrm{n}=32\right)$ and $2010\left(\mathrm{R}^{2}=0.7002, \mathrm{P}<0.0001, \mathrm{n}=32\right)$. However, the effect of $\mathrm{P}$ 340 fertiliser application on tuber yield was less in 2009 than in 2010 (Fig. 1A). Expressing the response of 341 tuber yield to P-fertiliser application as (1-(yield unfertilised / yield fertilised)) x 100, this value averaged $3424.78 \%$ across all genotypes in 2009 and $13.13 \%$ across all genotypes in 2010 . The response of tuber yield 343 to P-fertiliser application, averaged across both years, did not differ significantly between Tuberosum, 344 Phureja or Diploid Hybrid genotypes (Table 2).

345 There was also a strong positive relationship between $[\mathrm{P}]_{\text {leaf }}$ when grown without P-fertiliser 346 application and $[\mathrm{P}]_{\text {leaf }}$ when grown with P-fertiliser application among genotypes (Fig. 1B) in both 2009 $347\left(\mathrm{R}^{2}=0.3515, \mathrm{P}=0.0003, \mathrm{n}=32\right)$ and $2010\left(\mathrm{R}^{2}=0.6139, \mathrm{P}<0.0001, \mathrm{n}=32\right)$. In 2009, $[\mathrm{P}]_{\text {leaf }}$ averaged across all 348 genotypes was $2.8 \%$ greater in plants grown with P-fertiliser application than in plants grown without $\mathrm{P}$ 349 fertiliser application. In 2010, $[\mathrm{P}]_{\text {leaf }}$ averaged across all genotypes was 5.5\% greater in plants grown with 350 P-fertiliser application than in plants grown without P-fertiliser application. 
No significant relationships among genotypes between tuber yield and $[\mathrm{P}]_{\text {leaf }}$ nor between $[\mathrm{P}]_{\text {tuber }}$ and $[\mathrm{P}]_{\text {leaf }}$ were observed in any year or for any P-fertiliser application rate, although the relationships between $[\mathrm{P}]_{\text {tuber }}$ and $[\mathrm{P}]_{\text {leaf }}$ among genotypes generally showed a positive trend (Tables 1,2$)$ The $[\mathrm{P}]_{\text {tuber }} /$ $[P]_{\text {leaf }}$ quotients averaged across all genotypes receiving P-fertiliser applications were $0.49 \pm 0.013(n=64)$, $0.47 \pm 0.012(\mathrm{n}=63), 0.44 \pm 0.020(\mathrm{n}=32)$, and $0.53 \pm 0.015(\mathrm{n}=32)$ in 2006, 2007, 2009 and 2010, respectively. These data are consistent with $[\mathrm{P}]_{\text {tuber }} /[\mathrm{P}]_{\text {leaf }}$ quotients obtained in previous studies of the same genotypes and the observation that $\mathrm{P}$ is relatively mobile in the phloem of potato plants (e.g. Kärenlampi and White 2009; White 2018).

Agronomic phosphorus use efficiency (PUE) is defined as tuber yield per unit of $\mathrm{P}$ available in the soil (Fernandes and Soratto 2016a; Sandaña 2016; White et al. 2005a). Assuming similar biomass and P partitioning among the potato genotypes studied here, the product of yield and $[\mathrm{P}]_{\text {leaf }}$ can be used as a proxy for PUpE and $[\mathrm{P}]_{\text {leaf }}$ can be used as a reciprocal proxy for PUtE such that smaller $[\mathrm{P}]_{\text {leaf }}$ indicates greater PUtE (White et al. 2005a). In the experiments reported here, PUE appears to be strongly correlated with the product of yield and $[\mathrm{P}]_{\text {leaf }}(\mathrm{PUpE})$ among genotypes (Fig. 2B; $\mathrm{R}^{2}=0.7087, \mathrm{P}<0.0001, \mathrm{n}=128$ ), with $[\mathrm{P}]_{\text {leaf }}$ (PUtE) varying little between genotypes (Tables 1,2), whether these values are obtained with or without the addition of P-fertiliser.

Relationships between the size of the juvenile root system, P acquisition, canopy development and tuber yield genotypes selected for contrasting yield (PUE), yield loss without P-fertiliser application, $[\mathrm{P}]_{\text {leaf }}(1 / \mathrm{PUtE})$ and the product of yield and $[\mathrm{P}]_{\text {leaf }}(\mathrm{PUpE})$. 'Nadine' is characterised by high yields, high yield loss without P-fertiliser application, low [P] $]_{\text {leaf }}$ and high PUtE (Tables 1,2). 'Maris Piper' is characterised by high yields, high yield loss without P-fertiliser application and good PUtE. 'Stirling' is characterised by high yields, low yield loss without P-fertiliser application and good PUtE. 'Cara' is characterised by medium yields, low yield loss without P-fertiliser application, high $[\mathrm{P}]_{\text {leaf }}$ and high PUtE. 'Ailsa' is characterised by low yields, low yield loss without P-fertiliser application, high $[\mathrm{P}]_{\text {leaf }}$ and average PUtE. 'Home Guard' is characterised by low yield, low yield loss without P-fertiliser application, low $[\mathrm{P}]_{\text {leaf }}$ and low PUtE. 'Pentland Dell' is characterised by low yields, low [P] $]_{\text {leaf }}$ and low PUtE. Genotype 12601ab1, a processing clone with high dry matter content, is characterised by low yields, high $[\mathrm{P}]_{\text {leaf }}$ and low PUtE.

There was a strong linear relationship between root DW and shoot DW at crop establishment in the field across both P-fertiliser treatments for the eight Tuberosum genotypes selected for study (Fig. 3; $\mathrm{R}^{2}=0.7499, \mathrm{P}<0.0001, \mathrm{n}=16$ ). The application of $\mathrm{P}$-fertiliser increased both root and shoot DWs. The genotype 'Ailsa' had the largest root DW and 'Pentland Dell' had the smallest root dry weight of the eight genotypes studied in the absence of P-fertiliser application. There were also strong linear relationships between root DW at crop establishment and (1) the time to reach canopy closure (Fig. 4; $\mathrm{R}^{2}=0.6128$, 
$\mathrm{P}=0.0003, \mathrm{n}=16$ ) and (2) the plant $\mathrm{P}$ accumulated at crop establishment (Fig. 5; $\mathrm{R}^{2}=0.8098, \mathrm{P}<0.0001$, $\mathrm{n}=16$ ) across both P-fertiliser treatments for the eight Tuberosum genotypes studied. Differences in shoot and tuber DWs between plants grown with and without P-fertiliser application were maintained throughout the season, as illustrated for 'Stirling' in Fig. 6. However, the initial strong positive linear relationship between root DW at crop emergence and tuber DW among genotypes (Fig. 7 Harvest 2; R $^{2}=0.4216$, $\mathrm{P}=0.0064, \mathrm{n}=16$ ) became weaker as the season progressed and was not observed in tuber yields at the final harvest (Fig. 7 Harvest 6; $\mathrm{R}^{2}=0.0059, \mathrm{P}=0.7766$, $\mathrm{n}=16$ ). Similarly, the strong linear relationship between root DW and plant $\mathrm{P}$ accumulation observed at crop establishment in the field became weaker as the season progressed and was not observed at the final harvest (Fig. 5; $\mathrm{R}^{2}=0.0393, \mathrm{P}=0.4615, \mathrm{n}=16$ ). Nevertheless, plants supplied P-fertiliser had greater shoot and tuber $\mathrm{P}$ content, and (generally) higher $[\mathrm{P}]_{\text {shoot }}$ and $[\mathrm{P}]_{\text {tuber }}$ than plants grown without P-fertiliser applications throughout the season, as illustrated for 'Stirling' in Fig. 8. It was observed that both $[\mathrm{P}]_{\text {shoot }}$ and $[\mathrm{P}]_{\text {tuber }}$, decreased during the season, especially in plants that had received P-fertilisers, which is consistent with previous studies (e.g. Carpenter 1963; Harris 1992; Kolbe and Stephan-Beckmann 1997ab; White 2018). Tuber yield (PUE) was strongly correlated with plant P content (PUpE) but not with the yield / plant P content quotient (PUtE), whether these values were obtained with or without the addition of P-fertiliser (Fig. 9), as was observed by proxies in Experiments 1 and 2 (Tables 1,2; Fig. 2).

\section{Discussion}

The large P-fertiliser requirement of a potato crop is thought to be a consequence of the inability of its root system to acquire $\mathrm{P}$ effectively from the soil and it has been hypothesized that a vigorous juvenile root system will enhance P acquisition, accelerate canopy development and enable greater tuber yields (White et al. 2005b; White 2018).

Substantial genetic variation was observed in tuber yield, $[\mathrm{P}]_{\text {tuber, }},[\mathrm{P}]_{\text {leaf }}$ (a reciprocal proxy for

414 PUtE) and the product of yield and $[\mathrm{P}]_{\text {leaf }}$ (a proxy for PUpE) among Tuberosum, Phureja and Diploid 415 Hybrid genotypes grown in the field (Tables 1,2). This is consistent with previous observations that 416 Tuberosum genotypes generally yield more than Phureja genotypes when grown together in the same 417 environment (Cabello et al. 2012; Iwama and Nishibe 1989; Sattelmacher et al. 1990; Wishart et al. 2013, 418 2014) and reports that Tuberosum genotypes differ in their yield, $[\mathrm{P}]_{\text {tuber, }}[\mathrm{P}]_{\text {leaf }}$, and PUpE (see 419 Introduction). Thus, there appears to be significant genetic variation in PUtE and PUpE that might be harnessed to improve PUE in the potato crop.

The application of P-fertiliser increased tuber yields, which is consistent with many previous studies (Dampney et al. 2002; Harris 1992; Johnston et al. 1986; Rosen et al. 2014; White 2018), but did not affect $[\mathrm{P}]_{\text {leaf }}\left(\right.$ Table 2). The lack of a significant effect of P-fertiliser application on $[\mathrm{P}]_{\text {leaf }}$ was unexpected, but might be explained because the $[\mathrm{P}]_{\text {leaf }}$ of all genotypes studied were greater than the critical 
$425[\mathrm{P}]_{\text {leaf }}$ for a potato crop $\left(1.5-2.5 \mathrm{mg} \mathrm{g}^{-1} \mathrm{DW}\right.$, White 2018) whether or not P-fertiliser had been applied 426 (Table 2). Strong positive relationships were observed for both tuber yields and $[\mathrm{P}]_{\text {leaf }}$ among genotypes 427 grown with and without P-fertiliser application (Fig. 1). The strong positive relationship between tuber 428 yields when grown with and without P-fertiliser application among genotypes suggests that the genotypes 429 studied generally responded similarly to the application of P-fertiliser and is consistent with observations 430 that tuber yields of potato genotypes grown with low $\mathrm{P}$ inputs are correlated with their maximum yield 431 potential (e.g. Fernandes and Soratto 2016ab; Sattelmacher et al. 1990). However, genetic variation in yield 432 loss upon reduction of P-fertiliser input was observed (Table 2), which is consistent with studies suggesting 433 that potato genotypes can differ in their yield response to $\mathrm{P}$ availability (Daoui et al. 2014; Fernandes and 434 Soratto 2016a; Freeman et al. 1998; Hailu et al. 2017; Jenkins and Ali 1999; Manorama et al. 2017; 435 Nyiraneza et al. 2017; Sandaña 2016; Sandaña and Kalazich 2015; Soratto and Fernandes 2016; Soratto et 436 al. 2015; Thornton et al. 2014; Trehan and Singh 2013).

437 The relationship between $[\mathrm{P}]_{\text {leaf }}$ (a proxy for 1/PUtE) and tuber yield among Tuberosum, Phureja 438 and Diplioid Hybrid genotypes was weak (Fig. 2A; $\mathrm{R}^{2}=0.0207, \mathrm{P}=0.1056, \mathrm{n}=128$ ), but, there was a strong 439 positive relationship between tuber yield and the product of yield and $[\mathrm{P}]_{\text {leaf }}$ (a proxy for PUpE) (Fig $2 \mathrm{~B}$; $\left.440 \mathrm{R}^{2}=0.7087, \mathrm{P}<0.0001, \mathrm{n}=128\right)$. These observations are consistent with previous studies suggesting that 441 differences in PUE are correlated with PUpE, rather than PUtE, among potato genotypes (Balemi and 442 Schenk 2009; Fernandes and Soratto 2016a; Sandaña 2016; Sattelmacher et al. 1990; Soratto et al. 2015; 443 Thornton et al. 2014; Trehan and Sharma 2005; White 2018; White et al. 2005a). It has been hypothesised 444 that PUpE influences PUE by accelerating canopy development and radiation absorption (White et al. 445 2005b).

446 The relationships between tuber yield (PUE), $\mathrm{P}$ acquisition (PUpE) and physiological $\mathrm{P}$ utilisation (PUtE) were tested directly using eight Tuberosum genotypes with contrasting phenotypes grown with and 448 without P-fertiliser application in the field. Tuber yield (PUE) was strongly correlated with plant P content 449 (PUpE; $\mathrm{R}^{2}=0.6506, \mathrm{P}=0.0002, \mathrm{n}=16$ ) but not with the yield / plant $\mathrm{P}$ content quotient (PUtE; $\mathrm{R}^{2}=0.0255$, $450 \mathrm{P}=0.5550, \mathrm{n}=16$ ), whether these values were obtained with or without the addition of P-fertiliser (Fig. 9), 451 suggesting that root traits contributed most to PUE in potato. It was observed that juvenile root vigour was 452 correlated with accelerated canopy development during crop establishment (Fig. 3), and greater P 453 acquisition (Fig. 5) and tuber biomass accumulation (Fig. 7) during the early season. These observations are 454 consistent with the hypothesis that rapid development of the root system enhances the ability of the potato 455 crop to acquire P to enable plant growth and canopy development (White 2018; White et al. 2005b). 456 Accelerated canopy development should enable greater accumulation of photosynthetically active radiation 457 and greater tuber yields (Balemi et al. 2009; Harris 1992; Jenkins and Ali 1999; Rosen et al. 2014; Sandaña 458 and Kalazich 2015). However, the relationships between root mass at establishment and $\mathrm{P}$ acquisition and 459 tuber yield became weaker during the season (Figs 5, 7). The latter might reflect the indirect effect of 460 juvenile roots on plant growth and biomass accumulation (White et al. 2005b). Other factors, such as 461 differences in photosynthetic efficiency, haulm longevity, root system senescence and biomass partitioning 
462 (Harvest Index) between genotypes are likely to contribute to the weakening of the relationship between root mass at establishment and tuber yield as the season progresses (Balemi 2009; Sandaña and Kalazich 2015; Soratto et al. 2015).

In conclusion, there is genetic variation within Solanum tuberosum in tuber yield, $\mathrm{P}$ acquisition (PUpE) and physiological P utilisation (PUtE). Tuber yield (PUE) is strongly positively correlated with PUpE, but not PUtE. One mechanism to achieve greater PUpE is to enhance juvenile root vigour, which is correlated with greater $\mathrm{P}$ acquisition, accelerated canopy development, and tuber biomass accumulation early in the season. Improving juvenile root vigour should, therefore, improve tuber yields of early varieties and short season crops. It is likely that the effect of juvenile root vigour will depend upon soil P availability and will be greater in soils with low $\mathrm{P}$ availability. Juvenile root vigour is a heritable trait and can be selected to improve the PUE of potato. The next step in developing potato genotypes with greater juvenile root vigour, PUpE and potential yield will be to identify the genetic basis of these traits by, for example, the detection of Quantitative Trait Loci using genetic-mapping populations (Bradshaw 2017; Fernandez-Pozo et al. 2015).

This work was supported by funding from the UK Department of Environment, Food and Rural Affairs (Projects HH3504SPO, HH3507SFV), the Rural and Environment Science and Analytical Services Division of the Scottish Government through its Strategic Research Programmes (2006-2011, 2011-2016, 2016-2021), and the European Community under both the Seventh Framework Programme for Research, Technological Development and Demonstration Activities through the Integrated Project NUE-CROPS (FP7-CP-IP 222645) and the Horizon 2020 Research and Innovation Programme through the SolACE Project (Grant number 727247). Nithya K. Subramanian was supported by a Research Scholarship from the International Office of the University of Nottingham and an SCRI-Universities Ph.D. Scholarship from The Scottish Crop Research Institute. We thank Gavin Ramsay, Rory Hayden, Michael Adu, Amy Gimson, Emma Shaw, Bruna Arruda, Joice Heidemann, Ralph Wilson, Euan Caldwell and the Farm Staff at the James Hutton Institute for their help with field trials and laboratory experiments. We thank Martin Broadley and Konrad Neugebauer for their comments on a draft version of the manuscript. The views expressed in this publication are the sole responsibility of the authors and do not necessarily reflect the views of the European Commission. Neither the European Commission nor any person acting on behalf of the Commission is responsible for the use which might be made of the information contained herein. 
Ahmadi SH, Agharezaee M, Kamgar-Haghighi AA, Sepaskhah AR (2017) Compatibility of root growth and tuber production of potato cultivars with dynamic and static water-saving irrigation managements. Soil Use Manage 33:106-119

Allen EJ, Scott RK (1992) Principles of agronomy and their application in the potato industry. In: Harris JM (ed) The potato crop: the scientific basis for improvement. London, Chapman and Hall, pp 816-881

Allison MF, Fowler JH, Allen EJ (2001) Effects of soil- and foliar-applied phosphorus fertilizers on the potato (Solanum tuberosum) crop. J Agric Sci 137: 379-395

Balemi T (2009) Effect of phosphorus nutrition on growth of potato genotypes with contrasting phosphorus efficiency. Afr Crop Sci J 17:199-212

Balemi T (2011) Screening for genotypic variation in potato for phosphorus efficiency. Int Res J Plant Sci 2:233-243

Balemi T, Schenk MK (2009) Genotypic variation of potato for phosphorus efficiency and quantification of phosphorus uptake with respect to root characteristics. J Plant Nutr Soil Sci 172:669-677

Bethke PC, Jansky SH (2008) The effects of boiling and leaching on the content of potassium and other minerals in potatoes. J Food Sci 73:H80-H85

Bradshaw JE (2017) Review and analysis of limitations in ways to improve conventional potato breeding. Potato Res 60:171-193

Bradshaw JE, Hackett CA, Pande B, Waugh R, Bryan GJ (2008) QTL mapping of yield, agronomic and quality traits in tetraploid potato (Solanum tuberosum subsp. tuberosum). Theor Appl Genet 116:193-211

Burns IG, Hammond JP, White PJ (2010) Precision placement of fertiliser for optimising the early nutrition of vegetable crops - a review of the implications for the yield and quality of crops, and their nutrient use efficiency. Acta Hortic 852:177-187

Cabello R, De Mendiburu F, Bonierbale M, Monneveux P, Roca W, Chujoy E (2012) Large-scale evaluation of potato improved varieties, genetic stocks and landraces for drought tolerance. Am J Potato Res 89:400-410

Carpenter PN (1963) Bulletin 610. Mineral accumulation in potato plants as affected by fertilizer application and potato variety. University of Maine, Orono

Dampney P, Johnson P, Goodlass G, Dyer C, Sinclair A, Edwards T (2002) Review of the response of potatoes to phosphate. Final Report on Defra Project PE0108. Department for Environment, Food and Rural Affairs, London

Daoui K, Mrabet R, Benbouaza A, Achbani EH (2014) Responsiveness of different potato (Solanum tuberosum) varieties to phosphorus fertilizer. Procedia Eng 83:344-347

Davenport JR, Milburn PH, Rosen CJ, Thornton RE (2005) Environmental impacts of potato nutrient management. Am J Potato Res 82:321-328 
Dechassa N, Schenk MK, Claasen N, Steingrobe B (2003) Phosphorus efficiency of cabbage (Brassica oleracea L. var. capitata), carrot (Daucus carota L.), and potato (Solanum tuberosum L.). Plant Soil 250:215-224

Department for Environment, Food and Rural Affairs [Defra] (2010) Fertiliser manual (RB209), 8th edn. The Stationery Office, London

Department for Environment, Food and Rural Affairs [Defra] (2017) The British survey of fertiliser practice. Fertiliser use on farm crops for crop year 2016. Department for Environment, Food and Rural Affairs and The Scottish Government, London

Ereifej KI, Shibli RA, Ajlouni MM, Hussein A (1998) Mineral contents of whole tubers and selected tissues of ten potato cultivars grown in Jordan. J Food Sci Technol 35:55-58

Fageria NK, Baligar VC, Jones CA (2011) Growth and mineral nutrition of field crops, 3rd edn. CRC Press, Boca Raton

Fernandes AM, Soratto RP (2013) Absorption and nutrients use efficiency by potato cultivars. Biosci J 29:91-100

Fernandes AM, Soratto RP (2016a) Response of potato cultivars to phosphate fertilization in tropical soils with different phosphorus availabilities. Potato Res 59:259-278

Fernandes AM, Soratto RP (2016b) Phosphorus fertilizer rate for fresh market potato cultivars grown in tropical soil with low phosphorus availability. Am J Potato Res 93:404-414

Fernandes AM, Soratto RP, Gonsales JR (2014) Root morphology and phosphorus uptake by potato cultivars grown under deficient and sufficient phosphorus supply. Sci Hortic 180:190-198

Fernandes AM, Soratto RP, Pilon C (2015) Soil phosphorus increases dry matter and nutrient accumulation and allocation in potato cultivars. Am J Potato Res 92: 117-127

Fernandez-Pozo N, Menda N, Edwards JD, Saha S, Tecle IY, Strickler SR, Bombarely A, Fisher-York T, Pujar A, Foerster H, Yan AM, Mueller LA (2015) The Sol Genomics Network (SGN) - from genotype to phenotype to breeding. Nucleic Acids Res 43:D1036-D1041.

Fixen PE, Bruulsema TW (2014) Potato management challenges created by phosphorus chemistry and plant roots. Am J Potato Res 91:121-131

Freeman KL, Franz PR, de Jong RW (1998) Effect of phosphorus on the yield, quality and petiolar phosphorus concentrations of potatoes (cvv. Russet Burbank and Kennebec) grown in the krasnozem and duplex soils of Victoria. Aust J Exp Agric 38:83-93

Hailu G, Nigussie D, Ali M, Derbew B (2017) Nitrogen and phosphorus use efficiency in improved potato (Solanum tuberosum L.) cultivars in southern Ethiopia. Am J Potato Res 94:617-631

Hammond JP, Broadley MR, White PJ, King GJ, Bowen HC, Hayden R, Meacham MC, Mead A, Overs T, Spracklen WP, Greenwood DJ (2009) Shoot yield drives phosphorus use efficiency in Brassica oleracea and correlates with root architecture traits. J Exp Bot 60:1953-1968

Harris PM (1992) Mineral nutrition. In: Harris JM (ed) The potato crop: the scientific basis for improvement. Chapman and Hall, London, pp 162-213 
Haverkort AJ (2007) Potato crop response to radiation and daylength. In: Vreugdenhil D (ed) Potato biology and biotechnology: advances and perspectives. Elsevier, Amsterdam, pp 353-365

Hopkins BG, Horneck DA, MacGuidwin AE (2014) Improving phosphorus use efficiency through potato rhizosphere modification and extension. Am J Potato Res 91:161-174

Iwama K (1998). Development of nodal and lateral roots in potato under field conditions. J Fac Agric Hokkaido Univ 68:33-44

Iwama K (2008) Physiology of the potato: New insights into root system and repercussions for crop management. Potato Res 51:333-353

Iwama K, Nishibe S (1989) Comparison of root characters among cultivated potatoes (Solanum tuberosum) and their wild relatives. Jpn J Crop Sci 58:126-132

Iwama K, Nakaseko K, Isoda A, Gotoh K, Nishibe Y (1981a) Relations between root system and tuber yield in the hybrid population of the potato plants. Jpn J Crop Sci 50:233-238

Iwama K, Nakaseko K, Isoda A, Gotoh K, Nishibe Y (1981b) Comparison of root systems among hybrid populations derived from different crosses in potato (Solanum tuberosum). Jpn J Crop Sci 50:365372

Iwama K, Hasegawa T, Nakaseko K (1999) New potato lines with high productivity and drought tolerance. In: Proceedings of the international symposium on world food security, Kyoto, Japan, pp 189-193

Jefferies RA (1993) Cultivar responses to water stress in potato: effects of shoot and roots. New Phytol 123:491-498

Jenkins PD, Ali H (1999) Growth of potato cultivars in response to phosphate fertiliser. Ann Appl Biol 135:431-438

Johnston AE, Lane PW, Mattingley GEG, Poulton PR, Hewitt MV (1986) Effects of soil and fertilizer P on yields of potatoes, sugar beet, barley and winter wheat on a sandy clay loam soil at Saxmundham, Suffolk. J Agric Sci 106:155-167

Kärenlampi SO, White PJ. 2009. Potato proteins, lipids and minerals. In: Singh J, Kaur L (eds) Advances in potato chemistry and technology. Academic Press, London pp 99-126

Kolbe H, Stephan-Beckmann S (1997a) Development, growth and chemical composition of the potato crop (Solanum tuberosum L.). I. Leaf and stem. Potato Res 40:111-129

Kolbe H, Stephan-Beckmann S (1997b) Development, growth and chemical composition of the potato crop (Solanum tuberosum L.). II. Tuber and whole plant. Potato Res 40:135-153

Kratzke MG, Palta JP (1992) Variations in stolon length and in incidence of tuber roots among eight potato cultivars. Am Potato J 69:561-570

Lahlou O, Ledent J-F (2005) Root mass and depth, stolons and roots formed on stolons in four cultivars of potato under water stress. Eur J Agron 22:159-173

Lee WC, Liu G, Alva AK (2013) Potato cultivar evaluation for phosphorus-use efficiency. J Crop Improv 27:617-626 
608

609

610

611

612

613

614

615

616

617

618

619

620

621

622

623

624

625

626

627

628

629

630

631

632

633

634

635

636

637

638

639

640

641

642

643

Leonel M, do Carmo EL, Fernandes AM, Soratto RP, Eburneo JAM, Garcia EL, dos Santos TPR (2017) Chemical composition of potato tubers: the effect of cultivars and growth conditions. J Food Sci Technol 54:2372-2378

Lombardo S, Pandino G, Mauromicale G. 2014. The mineral profile in organically and conventionally grown "early" crop potato tubers. Sci Hortic 167:169-173

MacKerron DKL, Peng ZY. 1989. Genotypic comparisons of potato root growth and yield response to drought. Asp of Appl Biol 22:199-206

Manorama K, Govindakrishnan P, Lal SS (2017) Phosphorus efficient potato cultivars for Nilgiris. Indian J Hortic 74:618-622

McCord PH, Sosinski BR, Haynes KG, Clough ME, Yencho GC (2011) Linkage mapping and QTL analysis of agronomic traits in tetraploid potato (Solanum tuberosum subsp. tuberosum). Crop Sci 51:771-785

Nyiraneza J, Bizimungu B, Messiga AJ, Fuller KD, Fillmore SAE, Jiang Y (2017) Potato yield and phosphorus use efficiency of two new potato cultivars in New Brunswick, Canada. Can J Plant Sci 97:784-795

O’Brien PJ, Allen EJ, Firman DM (1998) A review of some studies into tuber initiation in potato (Solanum tuberosum) crops. J Agric Sci 130:251-270

Olsen SR, Cole CV, Watanabe FS, Dean LA (1954) USDA Circular 939. Estimation of available phosphorus in soil by extraction with sodium bicarbonate. US Government Printing Office, Washington

Opena GB, Porter GA (1999) Soil management and supplemental irrigation effects on potato: II. Root growth. Agron J 91:426-431

Puértolas J, Ballester C, Elphinstone ED, Dodd IC (2014) Two potato (Solanum tuberosum) varieties differ in drought tolerance due to differences in root growth at depth. Funct Plant Biol 41:1107-1118

Randhawa KS, Sandhu KS, Kaur G, Singh D (1984) Studies of the evaluation of different genotypes of potato (Solanum tuberosum L.) for yield and mineral contents. Qual Plant 34:239-242

Rasband WS (2014) ImageJ. US National Institutes of Health, Bethesda. http://imagej.nih.gov/ij/

Ruark MD, Kelling KA, Good LW (2014) Environmental concerns of phosphorus management in potato production. Am J Potato Res 91:132-144

Sandaña P (2016) Phosphorus uptake and utilization efficiency in response to potato genotype and phosphorus availability. Eur J Agron 76:95-106

Sandaña P, Kalazich J (2015) Ecophysiological determinants of tuber yield as affected by potato genotype and phosphorus availability. Field Crops Res 180:21-28

Sattelmacher B, Kuene R, Malagamba P, Moreno U (1990) Evaluation of tuber bearing Solanum species belonging to different ploidy levels for its yielding potential at low soil fertility. Plant Soil 129:227-233 
Soratto RP, Fernandes AM (2016) Phosphorus effects on biomass accumulation and nutrient uptake and removal in two potato cultivars. Agron J 108:1225-1236

Soratto RP, Pilon C, Fernandes AM, Moreno LA (2015) Phosphorus uptake, use efficiency, and response of potato cultivars to phosphorus levels. Potato Res 58:121-134

Stalham MA, Allen EJ (2001) Effect of variety, irrigation regime and planting date on depth, rate, duration and density of root growth in the potato (Solanum tuberosum) crop. J Agric Sci 137:251-270

Steckel JRA, Gray D (1979) Drought tolerance in potatoes. J Agric Sci 92:375-381

Subramanian NK, White PJ, Broadley MR, Ramsay G (2011) The three-dimensional distribution of minerals in potato tubers. Ann Bot 107: 681-691

Syers JK, Johnston AE, Curtin D (2008) FAO fertilizer and plant nutrition bulletin 18. Efficiency of soil and fertilizer phosphorus use. Food and Agriculture Organization of the United Nations, Rome

Tekalign T, Hammes PS (2005) Growth and productivity of potato as influenced by cultivar and reproductive growth. II. Growth analysis, tuber yield and quality. Sci Hortic 105:29-44

Thornton MK, Novy RG, Stark JC (2014) Improving phosphorus use efficiency in the future. Am J Potato Res 91:175-179

Trehan SP, Sharma RC (2003) External phosphorus requirement of different potato (Solanum tuberosum) cultivars resulting from different internal requirements and uptake efficiencies. Indian J Agric Sci 73:54-56

Trehan SP, Sharma RC. 2005. Differences in phosphorus use efficiency in potato genotypes. Adv Hortic Sci 19:13-20

Trehan SP, Singh BP (2013) Nutrient efficiency of different crop species and potato varieties - in retrospect and prospect. Potato J 40:1-21

Van Loon CD (1986) Drought, a major constraint in potato production and possibilities for screening for drought resistance. In: Beekman AGB et al. (Eds) Potato research of tomorrow. Pudoc, Wageningen, pp 5-16

White PJ (2018) Improving nutrient management in potato cultivation. In: Wale S (ed) Achieving sustainable cultivation of potatoes. Vol. 2: Production and storage, crop protection and sustainability. Burleigh Dodds, Cambridge, in press.

White PJ, Hammond JP (2008) Phosphorus nutrition of terrestrial plants. In: White PJ, Hammond JP (eds) The ecophysiology of plant-phosphorus interactions. Springer, Dordrecht, pp 51-81

White PJ, Broadley MR, Greenwood DJ, Hammond JP (2005a) Proceedings of The International Fertiliser Society 568. Genetic modifications to improve phosphorus acquisition by roots. International Fertiliser Society, York

White PJ, Broadley MR, Hammond JP, Thompson AJ (2005b) Optimising the potato root system for phosphorus and water acquisition in low-input growing systems. Asp Appl Biol 73:111-118

White PJ, Wheatley RE, Hammond JP, Zhang K (2007) Minerals, soils and roots. In: Vreugdenhil D (ed) Potato biology and biotechnology: advances and perspectives. Elsevier, Amsterdam, pp 739-752 
681 White PJ, Bradshaw JE, Dale MFB, Ramsay G, Hammond JP, Broadley MR (2009) Relationships between yield and mineral concentrations in potato tubers. HortScience 44:6-11

683 White PJ, Broadley MR, Hammond JP, Ramsay G, Subramanian NK, Thompson J, Wright G (2012)

684 Biofortification of potato tubers using foliar zinc-fertilisers. J Hortic Sci Biotechnol 87:123-129

685 White PJ, George TS, Gregory PJ, Bengough AG, Hallett PD, McKenzie BM (2013) Matching roots to 686 their environment. Ann Bot 112:207-222

687 Wishart J, George TS, Brown LK, Ramsay G, Bradshaw JE, White PJ, Gregory PJ (2013) Measuring

688 variation in potato roots in both field and glasshouse: the search for useful yield predictors and a

689 simple screen for root traits. Plant Soil 368:231-249

690 Wishart J, George TS, Brown LK, White PJ, Ramsay G, Jones HG, Gregory PJ (2014) Field phenotyping

691 of potato to assess root and shoot characteristics associated with drought tolerance. Plant Soil

$692 \quad 378: 351-363$

693 
694

695

696

697

698

699

700

701

702

703

704

705

706

707

708

709

710

711

712

713

714

715

716

717

718

719

720

721

722

723

724

725

726

727

728

729

730

731

\section{Figure Legends}

Fig. 1 (a) Relationship between tuber FW yield per plot of five plants for 32 Solanum tuberosum genotypes cultivated in the field with or without P-fertiliser application in 2009 (circles; $y=0.9814 x+0.7368$, $\mathrm{R}^{2}=0.8836, \mathrm{P}<0.0001, \mathrm{n}=32$ ) and 2010 (squares, $\mathrm{y}=1.1255 \mathrm{x}+0.7198, \mathrm{R}^{2}=0.7002, \mathrm{P}<0.0001, \mathrm{n}=32$ ). (b) Relationship between $[\mathrm{P}]_{\text {leaf }}$ of plants grown without $\mathrm{P}$-fertiliser application and $[\mathrm{P}]_{\text {leaf }}$ of plants grown with $\mathrm{P}$-fertiliser application for 32 Solanum tuberosum genotypes grown in the field in 2009 (circles; $\mathrm{y}=4901 \mathrm{x}+$ 2.0065, $\mathrm{R}^{2}=0.3515, \mathrm{P}=0.0003, \mathrm{n}=32$ ) and 2010 (squares; $\mathrm{y}=0.9501 \mathrm{x}+0.3139, \mathrm{R}^{2}=0.6139, \mathrm{P}<0.0001$, $\mathrm{n}=32$ ). All data are means of 2 plots. Group Tuberosum = black symbols; Group Phureja = purple symbols; Diploid Hybrids = blue symbols. Lines indicate a quotient of unity.

Fig. 2 The relationships between tuber FW yield $\left(\mathrm{kg} \mathrm{plot}^{-1}\right)$ and (a) $\mathrm{P}$ concentration of diagnostic leaves $\left([\mathrm{P}]_{\text {leaf }}\right)$ or $(\mathrm{b})$ the product of tuber yield and $[\mathrm{P}]_{\text {leaf }}$ quotient for 32 Solanum tuberosum genotypes grown in the field with (closed symbols) or without (open symbols) P-fertiliser application in 2009 (circles) or 2010 (squares). Data are means of 2 plots. Linear regression of all data presented in panel (a) yielded $y=14.56-$ $0.8493 x\left(R^{2}=0.0207, P=0.1056, n=128\right)$. Linear regression of all data presented in panel $(b)$ yielded $y=$ $2.494+2.274 x\left(\mathrm{R}^{2}=0.7087, \mathrm{P}<0.0001, \mathrm{n}=128\right)$.

Fig. 3 The relationship between root mass and shoot mass of eight Tuberosum genotypes three weeks after emergence (Harvest 1). Data show means of four individual plants grown with (closed circles) or without (open circles) P-fertiliser application. Linear regression of all data yielded $y=8.871 x-14.01\left(\mathrm{R}^{2}=0.7499\right.$, $\mathrm{P}<0.0001, \mathrm{n}=16)$.

Fig. 4 The relationship between root mass of eight Tuberosum genotypes three weeks after emergence (Harvest 1) and the days after crop emergence to reach 50\% canopy closure. Data show means of four individual plants grown with (closed circles) or without (open circles) P-fertiliser application. Linear regression of all data yielded $y=44.09 x-1.806\left(R^{2}=0.6128, P=0.0003, n=16\right)$.

Fig. 5 Relationships between the root DWs at establishment (Harvest 1) of eight Tuberosum genotypes and their P content at establishment (Harvest 1), close to canopy closure (Harvest 3) and at final harvest (Harvest 6). Data for root DWs are means of four individual plants and data for plant P content are means of two replicate plots of five plants cultivated with (closed symbols) or without (open symbols) P-fertiliser application. Regression lines were $\mathrm{y}=0.1411 \mathrm{x}-0.1230\left(\mathrm{R}^{2}=0.8098, \mathrm{P}<0.0001, \mathrm{n}=16\right.$, Harvest 1$), \mathrm{y}=$ $0.201 \mathrm{x}+1.4243\left(\mathrm{R}^{2}=0.4419, \mathrm{P}=0.0050, \mathrm{n}=16\right.$, Harvest 3$)$, and $\mathrm{y}=0.0778 \mathrm{x}+3.8214\left(\mathrm{R}^{2}=0.0393\right.$, $\mathrm{P}=0.4615, \mathrm{n}=16$, Harvest 6).

Fig. 6 The accumulation of (a) shoot mass, (b) tuber mass in the Tuberosum genotype 'Stirling'. Data are shown as individual plots of five plants grown with (closed circles) or without (open circles) P-fertiliser 
732 application. Plants were harvested at establishment (Harvest 1), when the canopy had approximately 50\%

733 ground cover (Harvest 2), close to canopy closure (Harvest 3), mid-canopy duration (Harvest 4), when the

734 canopy had begun to sag (Harvest 5), and two weeks after canopy sagging at final harvest (Harvest 6).

735

736 Fig. 7 Relationships between the root DWs at establishment (Harvest 1) of eight Tuberosum genotypes and their tuber DWs when the canopy had approximately 50\% ground cover (Harvest 2), when the canopy had full ground cover (Harvest 4) and at final harvest (Harvest 6). Data for root DWs are means of four individual plants and data for tuber DWs are means of two replicate plots of five plants cultivated with

740 (closed symbols) or without (open symbols) P-fertiliser application. Regression lines were $\mathrm{y}=0.052 \mathrm{x}-$ $0.0495\left(R^{2}=0.4216, P=0.0064, n=16\right.$, Harvest 2$) y=0.091 x+0.9392\left(R^{2}=0.2179, P=0.0683, n=16\right.$, Harvest 4) and $y=0.0176 x+2.6293\left(R^{2}=0.0059, P=0.7766, n=16\right.$, Harvest 6$)$.

744 Fig. 8 The accumulation of phosphorus in (a) shoots and (b) tubers, and the P concentrations in shoots (c) 745 and tubers (d) of the Tuberosum genotype 'Stirling'. Data are shown from individual plots of five plants 746 cultivated with (closed circles) or without (open circles) P-fertiliser application. Plants were harvested at 747 establishment (Harvest 1), when the canopy had approximately 50\% ground cover (Harvest 2), close to 748 canopy closure (Harvest 3), mid-canopy duration (Harvest 4), when the canopy had begun to sag (Harvest 749 5), and two weeks after canopy sagging at final harvest (Harvest 6).

751 Fig. 9 The relationships between tuber DW yield $\left(\mathrm{kg} \mathrm{plot}^{-1}\right)$ and (a) yield divided by plant $\mathrm{P}$ content (PUtE) 752 or (b) plant $\mathrm{P}$ content (PUpE) for eight Tuberosum genotypes grown in the field with (closed symbols) or 753 without (open symbols) P-fertiliser application. Data are means of 2 plots, each containing 5 plants. Linear 754 regression of all data presented in panel (a) yielded $\mathrm{y}=3.411-0.4254 \mathrm{x}\left(\mathrm{R}^{2}=0.0255, \mathrm{P}=0.5550, \mathrm{n}=16\right)$. 755 Linear regression of all data presented in panel (b) yielded $y=0.7208+0.4684 x\left(R^{2}=0.6506, P=0.0002\right.$, $756 \mathrm{n}=16)$. 
Table 1. Yields per plot of eight plants $\left(\mathrm{kg} \mathrm{FW} \mathrm{plot}^{-1}\right), \mathrm{P}$ concentration of diagnostic leaves ([P] leaf, $\left.\mathrm{mg} \mathrm{g}^{-1} \mathrm{DW}\right)$, $\mathrm{P}$ concentration of tubers $\left([\mathrm{P}]_{\mathrm{tuber}}, \mathrm{mg} \mathrm{g}^{-1} \mathrm{DW}\right)$ and yield $*[\mathrm{P}]_{\text {leaf }}$ for PUpE, for genotypes cultivated in Experiment 1. Data are expressed as mean $\pm \mathrm{SE}$ either for $\mathrm{n}$ years (for individual genotypes) or for $\mathrm{n}$ genotypes present in all years of Experiment 1 (2006, 2007, 2008).

\begin{tabular}{|c|c|c|c|c|c|c|c|c|c|c|c|c|c|}
\hline \multirow[b]{2}{*}{ Genotype } & \multirow[b]{2}{*}{ Group } & \multicolumn{3}{|c|}{$\begin{array}{c}\text { Tuber yield } \\
\left(\mathrm{kg} \mathrm{FW} \mathrm{plot}^{-1}\right)\end{array}$} & \multicolumn{3}{|c|}{$\begin{array}{c}{[\mathrm{P}]_{\text {leaf }}} \\
\left(\mathrm{mg} \mathrm{g}^{-1} \mathrm{DM}\right)\end{array}$} & \multicolumn{3}{|c|}{$\begin{array}{c}{[\mathrm{P}]_{\text {tuber }}} \\
\left(\mathrm{mg} \mathrm{g}^{-1} \mathrm{DM}\right)\end{array}$} & \multicolumn{3}{|c|}{ Yield* $[\mathrm{P}]_{\text {leaf }}$} \\
\hline & & mean & $\mathrm{SE}$ & $\mathrm{n}$ & mean & SE & $\mathrm{n}$ & mean & SE & $\mathrm{n}$ & mean & SE & $\mathrm{n}$ \\
\hline 99.FT 1 (5) & Diploid Hybrid & 14.8 & & 1 & 3.10 & & 1 & 2.10 & & 1 & 45.89 & & 1 \\
\hline HB.165 (1) & Diploid Hybrid & 11.4 & 1.87 & 3 & 3.98 & 0.27 & 2 & 1.74 & 0.07 & 3 & 45.93 & 7.38 & 2 \\
\hline HB.171 (13) & Diploid Hybrid & 16.7 & 13.22 & 3 & 3.87 & 0.75 & 2 & 2.32 & 0.17 & 3 & 73.94 & 42.00 & 2 \\
\hline 2DH40 (3) & Diploid Tuberosum & 2.2 & & 1 & 3.90 & & 1 & 1.69 & & 1 & 8.47 & & 1 \\
\hline 71.P.10 & Phureja & 12.4 & 2.78 & 3 & 3.42 & 0.09 & 2 & 1.49 & 0.07 & 3 & 45.41 & 3.61 & 2 \\
\hline 71.T.46 & Phureja & 11.7 & 3.56 & 3 & 4.05 & 0.04 & 2 & 1.77 & 0.23 & 3 & 47.87 & 8.77 & 2 \\
\hline 71.T.6 & Phureja & 11.5 & 5.06 & 3 & 3.78 & 0.31 & 2 & 1.54 & 0.26 & 3 & 41.76 & 13.55 & 2 \\
\hline 80.СР.23 & Phureja & 10.9 & 3.14 & 3 & 4.26 & 0.80 & 2 & 1.36 & 0.12 & 3 & 41.89 & 4.26 & 2 \\
\hline 81.S.66 & Phureja & 15.6 & 3.52 & 3 & 3.42 & 0.33 & 2 & 1.57 & 0.14 & 3 & 53.63 & 12.05 & 2 \\
\hline 84.2.P75 & Phureja & 5.9 & 1.82 & 3 & 3.57 & 0.06 & 2 & 1.77 & 0.12 & 3 & 22.25 & 2.74 & 2 \\
\hline 85.1.T8 & Phureja & 12.7 & 2.70 & 3 & 3.98 & 0.67 & 2 & 1.68 & 0.01 & 3 & 48.68 & 12.19 & 2 \\
\hline DB.161 (10) & Phureja & 12.2 & 3.65 & 3 & 3.33 & 0.07 & 2 & 1.62 & 0.13 & 3 & 44.41 & 3.45 & 2 \\
\hline DB.168 (11) & Phureja & 8.0 & 4.10 & 3 & 3.67 & 0.11 & 2 & 1.27 & 0.02 & 3 & 32.19 & 8.21 & 2 \\
\hline DB.170 (35) & Phureja & 9.0 & 5.26 & 3 & 4.78 & 0.45 & 2 & 1.62 & 0.20 & 3 & 44.61 & 18.57 & 2 \\
\hline DB.175 (5) & Phureja & 10.9 & 7.07 & 3 & 3.71 & 0.16 & 2 & 1.49 & 0.14 & 3 & 42.19 & 12.67 & 2 \\
\hline DB.199 (10) & Phureja & 13.3 & 2.90 & 3 & 2.96 & 0.54 & 2 & 1.83 & 0.28 & 3 & 36.93 & 3.01 & 2 \\
\hline DB.207 (35) & Phureja & 11.8 & 4.59 & 3 & 4.07 & 0.22 & 2 & 1.92 & 0.23 & 3 & 48.94 & 13.40 & 2 \\
\hline DB.226 (70) & Phureja & 16.2 & 6.09 & 3 & 3.61 & 0.14 & 2 & 1.48 & 0.15 & 3 & 63.82 & 11.91 & 2 \\
\hline DB.244 (37) & Phureja & 14.8 & 2.92 & 3 & 3.34 & 0.37 & 2 & 1.60 & 0.19 & 3 & 47.79 & 0.09 & 2 \\
\hline DB.257 (28) & Phureja & 13.3 & 3.75 & 3 & 3.75 & 0.36 & 2 & 1.46 & 0.16 & 3 & 51.85 & 12.87 & 2 \\
\hline DB.270 (43) & Phureja & 14.6 & 15.11 & 3 & 4.01 & 0.42 & 2 & 1.72 & 0.22 & 3 & 66.11 & 40.83 & 2 \\
\hline DB.271 (39) & Phureja & 12.7 & 4.39 & 3 & 4.01 & 0.32 & 2 & 1.85 & 0.08 & 3 & 55.23 & 12.03 & 2 \\
\hline DB.299 (39) & Phureja & 12.2 & 4.07 & 3 & 3.84 & 0.44 & 2 & 1.21 & 0.08 & 3 & 49.25 & 14.13 & 2 \\
\hline DB.323 (3) & Phureja & 11.6 & 7.30 & 3 & 3.62 & 0.74 & 2 & 1.54 & 0.17 & 3 & 46.55 & 23.94 & 2 \\
\hline DB.333 (16) & Phureja & 16.0 & 7.51 & 3 & 3.66 & 0.46 & 2 & 2.12 & 0.28 & 3 & 50.47 & 4.13 & 2 \\
\hline DB.337 (37) & Phureja & 13.3 & 1.08 & 3 & 3.80 & 0.28 & 2 & 1.43 & 0.10 & 3 & 49.85 & 1.41 & 2 \\
\hline DB.354 (901) & Phureja & 12.8 & 9.96 & 3 & 3.82 & 0.43 & 2 & 1.48 & 0.20 & 3 & 55.67 & 26.38 & 2 \\
\hline DB.358 (23) & Phureja & 13.3 & 7.03 & 3 & 3.50 & 0.37 & 2 & 1.59 & 0.25 & 3 & 47.73 & 19.11 & 2 \\
\hline DB.358 (24) & Phureja & 9.2 & 2.97 & 3 & 3.64 & 0.63 & 2 & 1.21 & 0.14 & 3 & 35.01 & 12.08 & 2 \\
\hline DB.358 (30) & Phureja & 13.5 & 4.63 & 3 & 3.57 & 0.53 & 2 & 1.63 & 0.12 & 3 & 52.10 & 16.04 & 2 \\
\hline DB.375 (1) & Phureja & 11.0 & 7.09 & 3 & 3.10 & 0.56 & 2 & 1.33 & 0.11 & 3 & 36.69 & 18.92 & 2 \\
\hline DB.375 (2) & Phureja & 12.5 & 1.02 & 3 & 3.42 & 0.17 & 2 & 1.46 & 0.12 & 3 & 42.30 & 3.87 & 2 \\
\hline DB.377 (4) & Phureja & 10.5 & 3.07 & 3 & 3.48 & 0.27 & 2 & 1.34 & 0.07 & 3 & 33.12 & 0.59 & 2 \\
\hline DB.378 (1) & Phureja & 11.4 & 3.00 & 3 & 2.96 & 0.73 & 2 & 1.48 & 0.18 & 3 & 34.26 & 13.20 & 2 \\
\hline DB.384 (4) & Phureja & 12.4 & 2.10 & 3 & 3.46 & 0.07 & 2 & 1.54 & 0.05 & 3 & 44.42 & 2.17 & 2 \\
\hline DB.441 (2) & Phureja & 10.3 & 3.28 & 3 & 3.79 & 0.49 & 2 & 1.84 & 0.22 & 3 & 36.14 & 8.52 & 2 \\
\hline DB.520 (11) & Phureja & 8.5 & 3.82 & 3 & 3.95 & 0.27 & 2 & 1.26 & 0.14 & 3 & 38.21 & 7.47 & 2 \\
\hline PHU.95 (0412) & Phureja & 11.5 & 2.72 & 3 & 3.26 & 0.42 & 2 & 1.62 & 0.17 & 3 & 38.52 & 9.90 & 2 \\
\hline PHU.95 (1901) & Phureja & 9.3 & 2.89 & 3 & 3.44 & 0.38 & 2 & 2.41 & 0.16 & 3 & 32.07 & 1.91 & 2 \\
\hline TC.43 (45) & Phureja & 14.2 & 0.97 & 2 & 3.76 & 0.32 & 2 & 1.99 & 0.35 & 2 & 53.67 & 6.41 & 2 \\
\hline $12601 \mathrm{ab} 1$ & Tuberosum & 11.5 & 1.04 & 3 & 3.60 & 0.87 & 2 & 1.38 & 0.16 & 3 & 41.35 & 11.91 & 2 \\
\hline Ailsa & Tuberosum & 18.7 & 5.40 & 3 & 3.61 & 1.02 & 2 & 1.70 & 0.15 & 3 & 71.07 & 30.32 & 2 \\
\hline Anya & Tuberosum & 11.9 & 6.23 & 3 & 2.74 & 0.45 & 2 & 1.38 & 0.09 & 3 & 34.23 & 15.22 & 2 \\
\hline Brodick & Tuberosum & 18.1 & 2.72 & 3 & 3.17 & 0.53 & 2 & 1.69 & 0.18 & 3 & 54.99 & 11.24 & 2 \\
\hline Cara & Tuberosum & 21.3 & 8.80 & 3 & 4.06 & 0.72 & 2 & 1.71 & 0.21 & 3 & 87.73 & 35.14 & 2 \\
\hline Desiree & Tuberosum & 20.7 & 2.78 & 3 & 3.32 & 0.93 & 2 & 1.35 & 0.14 & 3 & 71.97 & 23.78 & 2 \\
\hline Edzell Blue & Tuberosum & 13.7 & & 1 & & & & 1.71 & & 1 & & & \\
\hline Estima & Tuberosum & 17.7 & 7.73 & 3 & 2.66 & 0.89 & 2 & 1.20 & 0.07 & 3 & 50.13 & 27.19 & 2 \\
\hline Eve Balfour & Tuberosum & 18.7 & & 1 & 2.62 & & 1 & 1.27 & & 1 & 48.90 & & 1 \\
\hline Golden Millenium & Tuberosum & 16.8 & 2.21 & 3 & 2.88 & 0.44 & 2 & 1.52 & 0.13 & 3 & 49.41 & 11.13 & 2 \\
\hline Harborough Harvest & Tuberosum & 15.5 & 6.21 & 3 & 4.17 & 0.95 & 2 & 1.72 & 0.18 & 3 & 60.95 & 0.33 & 2 \\
\hline Home Guard & Tuberosum & 14.3 & 2.39 & 3 & 2.57 & 1.05 & 2 & 1.38 & 0.32 & 3 & 36.90 & 17.61 & 2 \\
\hline Hermes & Tuberosum & 18.7 & 7.54 & 3 & 3.27 & 0.27 & 2 & 1.57 & 0.22 & 3 & 53.41 & 7.27 & 2 \\
\hline Lady Balfour & Tuberosum & 20.0 & & 1 & 2.76 & & 1 & 1.24 & & 1 & 55.36 & & 1 \\
\hline Maris Piper & Tuberosum & 23.5 & 3.70 & 3 & 3.22 & 0.52 & 2 & 1.60 & 0.09 & 3 & 76.04 & 18.77 & 2 \\
\hline Montrose & Tuberosum & 20.5 & 1.48 & 3 & 3.08 & 0.65 & 2 & 1.68 & 0.15 & 3 & 64.76 & 15.21 & 2 \\
\hline Nadine & Tuberosum & 22.3 & 7.81 & 3 & 3.10 & 1.34 & 2 & 1.81 & 0.25 & 3 & 59.29 & 17.16 & 2 \\
\hline Pentland Dell & Tuberosum & 14.2 & 3.66 & 3 & 2.59 & 0.90 & 2 & 1.42 & 0.09 & 3 & 39.95 & 18.12 & 2 \\
\hline Pentland Squire & Tuberosum & 20.7 & 6.08 & 3 & 3.76 & 0.98 & 2 & 1.69 & 0.15 & 3 & 78.70 & 32.14 & 2 \\
\hline Record & Tuberosum & 17.0 & 2.75 & 3 & 3.79 & 0.79 & 2 & 1.48 & 0.16 & 3 & 61.67 & 15.48 & 2 \\
\hline Saxon & Tuberosum & 18.7 & 5.18 & 3 & 2.53 & 0.61 & 2 & 1.55 & 0.16 & 3 & 49.61 & 19.16 & 2 \\
\hline Scarborough & Tuberosum & 19.2 & 1.85 & 3 & 3.27 & 0.38 & 2 & 1.63 & 0.20 & 3 & 64.77 & 8.97 & 2 \\
\hline Stirling & Tuberosum & 21.6 & 11.31 & 3 & 3.09 & 0.58 & 2 & 1.79 & 0.08 & 3 & 74.20 & 32.10 & 2 \\
\hline Tay & Tuberosum & 17.4 & 3.84 & 3 & 3.21 & 0.83 & 2 & 1.68 & 0.21 & 3 & 57.15 & 21.35 & 2 \\
\hline Vales Everest & Tuberosum & 20.0 & 4.31 & 3 & 3.61 & 1.03 & 2 & 1.70 & 0.17 & 3 & 78.09 & 26.51 & 2 \\
\hline Vales Sovereign & Tuberosum & 10.6 & & 1 & 3.48 & & 1 & 1.40 & & 1 & 36.77 & & 1 \\
\hline Wilja & Tuberosum & 22.8 & 4.56 & 3 & 3.33 & 0.85 & 2 & 1.58 & 0.14 & 3 & 75.62 & 26.67 & 2 \\
\hline *Mean, SE (3 years) & Diploid Hybrid & 14.0 & 2.6 & 2 & 3.93 & 0.06 & 2 & 2.03 & 0.29 & 2 & 59.93 & 14.00 & 2 \\
\hline & Phureja & 11.9 & 0.4 & 35 & 3.66 & 0.06 & 35 & 1.59 & 0.04 & 35 & 44.51 & 1.55 & 35 \\
\hline & Tuberosum & 18.4 & 0.7 & 23 & 3.25 & 0.10 & 23 & 1.57 & 0.03 & 23 & 60.52 & 3.08 & 23 \\
\hline
\end{tabular}


Table 2. Yields per plot of five plants $\left(\mathrm{kg} \mathrm{FW} \mathrm{plot}^{-1}\right), \mathrm{P}$ concentration of diagnostic leaves ([P] leaf, $\left.\mathrm{mg} \mathrm{g}^{-1} \mathrm{DW}\right), \mathrm{P}$ concentration of tubers $\left([\mathrm{P}]_{\text {tuber, }}, \mathrm{mg} \mathrm{g}^{-1} \mathrm{DW}\right)$ and yield $*$ $[\mathrm{P}]_{\text {leaf }}$ for genotypes cultivated either with (high P) or without (low P) P-fertiliser additions in Experiment $2(2009,2010)$. Yield loss for each genotype grown without Pfertiliser applications is expressed in percentage terms as (1-(yield unfertilised / yield fertilised)) x 100). Data are expressed as mean \pm SE either for $\mathrm{n}$ years (for individual genotypes) or for n genotypes.

\begin{tabular}{|c|c|c|c|c|c|c|c|c|c|c|c|c|c|c|c|c|c|c|c|c|}
\hline \multirow[b]{2}{*}{ Genotype } & \multirow[b]{2}{*}{ Group } & \multirow[b]{2}{*}{$\mathrm{n}$} & \multicolumn{2}{|c|}{$\begin{array}{l}\text { Yield (high P) } \\
\left(\mathrm{kg} \mathrm{FW} \mathrm{plot}^{-1}\right)\end{array}$} & \multicolumn{2}{|c|}{$\begin{array}{l}\text { Yield (low P) } \\
\left(\mathrm{kg} \mathrm{FW} \mathrm{plot}^{-1}\right)\end{array}$} & \multicolumn{2}{|c|}{$\begin{array}{c}\text { Yield loss } \\
(\%)\end{array}$} & \multicolumn{2}{|c|}{$\begin{array}{c}{[\mathrm{P}]_{\text {leaf }}(\text { high P })} \\
\left(\mathrm{m} \mathrm{g} \mathrm{g}^{-1} \mathrm{DM}\right)\end{array}$} & \multicolumn{2}{|c|}{$\begin{array}{c}{[P]_{\text {leaf }} \text { (low P) }} \\
\left(\mathrm{mg} \mathrm{g}^{-1} \mathrm{DM}\right)\end{array}$} & \multicolumn{2}{|c|}{$\begin{array}{c}{[\mathrm{P}] \text { ]uber (high P) }} \\
\left(\mathrm{mg} \mathrm{g}^{-1} \mathrm{DM}\right)\end{array}$} & \multicolumn{2}{|c|}{$\begin{array}{c}{[\mathrm{P}] \text { ]uber }(\text { low P })} \\
\left(\mathrm{mg} \mathrm{g}^{-1} \mathrm{DM}\right)\end{array}$} & \multicolumn{2}{|c|}{ Yield*[P]leat (high P) } & \multicolumn{2}{|c|}{ Yield*[P]leaf (low P) } \\
\hline & & & mean & SE & mean & $\mathrm{SE}$ & mean & $\mathrm{SE}$ & mean & $\mathrm{SE}$ & mean & SE & mean & SE & mean & SE & mean & $\mathrm{SE}$ & mean & $\mathrm{SE}$ \\
\hline 99.FT 1 (5) & Diploid Hybrid & 2 & 10.07 & 1.96 & 8.17 & 0.02 & 17.4 & 14.8 & 4.03 & 0.10 & 4.41 & 1.68 & 2.00 & 0.24 & 1.72 & 0.05 & 40.83 & 8.91 & 35.31 & 3.01 \\
\hline HB. 171 (13) & Diploid Hybrid & 2 & 5.72 & 0.27 & 6.15 & 0.02 & -7.1 & 20.8 & 3.83 & 0.28 & 3.63 & 0.52 & 2.80 & 0.04 & 2.31 & 0.40 & 21.95 & 2.60 & 22.09 & 1.59 \\
\hline DB. $226(70)$ & Phureja & 2 & 9.32 & 0.04 & 9.06 & 0.02 & 2.9 & 11.5 & 3.99 & 0.47 & 3.81 & 1.65 & 1.46 & 0.25 & 1.24 & 0.05 & 37.22 & 4.22 & 34.02 & 5.29 \\
\hline DB.337 (37) & Phureja & 2 & 10.99 & 0.07 & 9.46 & 0.01 & 13.9 & 2.4 & 3.91 & 0.32 & 3.41 & 0.56 & 1.73 & 0.04 & 1.56 & 0.01 & 43.00 & 3.30 & 32.16 & 2.03 \\
\hline DB. 375 (1) & Phureja & 2 & 8.52 & 3.65 & 5.86 & 0.01 & 25.2 & 27.8 & 3.47 & 0.30 & 2.84 & 0.56 & 1.43 & 0.04 & 1.32 & 0.08 & 28.47 & 10.13 & 16.24 & 2.76 \\
\hline DB.378 (1) & Phureja & 2 & 8.58 & 0.16 & 7.56 & 0.02 & 12.0 & 5.6 & 2.76 & 0.03 & 2.69 & 0.50 & 1.67 & 0.04 & 1.46 & 0.09 & 23.71 & 0.66 & 20.26 & 0.84 \\
\hline DB.384 (4) & Phureja & 2 & 8.05 & 0.00 & 7.11 & 0.01 & 11.8 & 8.2 & 3.62 & 0.57 & 3.26 & 0.62 & 1.55 & 0.15 & 1.57 & 0.04 & 29.13 & 4.54 & 23.26 & 3.27 \\
\hline DB.520 (11) & Phureja & 2 & 5.73 & 0.84 & 6.59 & 0.01 & -10.2 & 65.6 & 3.46 & 0.59 & 3.60 & 0.08 & 1.24 & 0.04 & 1.31 & 0.15 & 19.32 & 0.52 & 23.86 & 10.3 \\
\hline PHU.95 (1901) & Phureja & 2 & 5.11 & 1.02 & 5.30 & 0.03 & -5.4 & 17.6 & 3.33 & 0.43 & 2.93 & 0.67 & 2.09 & 0.47 & 1.77 & 0.13 & 16.60 & 1.21 & 15.32 & 0.06 \\
\hline 12601 ab 1 & Tuberosum & 2 & 8.78 & 1.51 & 7.81 & 0.01 & 10.4 & 6.9 & 4.12 & 0.38 & 4.20 & 0.86 & 1.38 & 0.02 & 1.42 & 0.05 & 35.56 & 2.87 & 32.34 & 1.07 \\
\hline Ailsa & Tuberosum & 2 & 12.19 & 2.38 & 11.87 & 0.02 & 0.8 & 19.0 & 4.13 & 0.33 & 3.66 & 0.62 & 1.90 & 0.15 & 1.60 & 0.03 & 49.52 & 5.85 & 43.05 & 0.70 \\
\hline Anya & Tuberosum & 2 & 9.86 & 1.55 & 8.76 & 0.01 & 13.8 & 33.6 & 2.86 & 0.20 & 3.48 & 1.49 & 1.56 & 0.07 & 1.35 & 0.01 & 27.85 & 2.43 & 28.25 & 3.89 \\
\hline Brodick & Tuberosum & 2 & 13.87 & 1.99 & 14.29 & 0.02 & -4.4 & 19.4 & 3.71 & 0.23 & 3.81 & 0.22 & 1.75 & 0.02 & 1.62 & 0.06 & 50.97 & 4.13 & 54.34 & 1.19 \\
\hline Cara & Tuberosum & 2 & 13.42 & 1.12 & 14.09 & 0.03 & -4.9 & 3.4 & 4.32 & 0.08 & 4.06 & 0.86 & 2.40 & 0.12 & 1.80 & 0.08 & 57.85 & 3.78 & 56.60 & 0.36 \\
\hline Desiree & Tuberosum & 2 & 13.09 & 1.90 & 12.97 & 0.02 & -0.2 & 14.6 & 3.47 & 0.55 & 3.08 & 1.01 & 1.63 & 0.08 & 1.44 & 0.00 & 44.34 & 0.65 & 39.52 & 3.64 \\
\hline Estima & Tuberosum & 2 & 14.63 & 1.00 & 12.74 & 0.01 & 12.9 & 1.2 & 2.87 & 0.76 & 3.04 & 1.46 & 1.20 & 0.03 & 1.25 & 0.11 & 41.23 & 8.32 & 38.12 & 6.89 \\
\hline Golden Millenium & Tuberosum & 2 & 13.99 & 0.07 & 12.27 & 0.01 & 12.3 & 17.7 & 3.23 & 0.20 & 2.94 & 0.47 & 1.51 & 0.03 & 1.62 & 0.13 & 45.13 & 2.64 & 35.80 & 0.90 \\
\hline Harborough Harvest & Tuberosum & 2 & 13.34 & 2.77 & 10.16 & 0.02 & 21.4 & 23.5 & 3.55 & 0.26 & 3.33 & 0.48 & 1.47 & 0.00 & 1.54 & 0.16 & 46.69 & 6.33 & 33.66 & 0.44 \\
\hline Home Guard & Tuberosum & 2 & 11.63 & 2.07 & 11.20 & 0.03 & 2.7 & 11.2 & 2.52 & 0.25 & 2.57 & 0.18 & 1.38 & 0.01 & 1.25 & 0.03 & 28.81 & 2.28 & 28.95 & 4.53 \\
\hline Hermes & Tuberosum & 2 & 15.96 & 1.24 & 11.45 & 0.02 & 26.9 & 35.1 & 3.98 & 0.69 & 4.14 & 0.78 & 1.50 & 0.12 & 1.33 & 0.13 & 62.66 & 6.12 & 48.21 & 12.3 \\
\hline Maris Piper & Tuberosum & 2 & 16.82 & 0.79 & 14.53 & 0.01 & 13.2 & 15.8 & 3.63 & 0.23 & 3.52 & 0.50 & 1.74 & 0.01 & 1.37 & 0.10 & 60.93 & 0.98 & 51.26 & 5.93 \\
\hline Montrose & Tuberosum & 2 & 14.40 & 2.88 & 11.98 & 0.01 & 14.1 & 26.9 & 3.37 & 0.42 & 3.21 & 0.33 & 1.59 & 0.14 & 1.68 & 0.13 & 47.32 & 3.70 & 38.31 & 0.28 \\
\hline Nadine & Tuberosum & 2 & 19.12 & 0.05 & 15.44 & 0.02 & 19.2 & 4.8 & 2.92 & 0.49 & 3.25 & 1.25 & 1.52 & 0.02 & 1.57 & 0.00 & 55.84 & 9.57 & 49.91 & 8.25 \\
\hline Pentland Dell & Tuberosum & 2 & 8.65 & 3.20 & 7.07 & 0.01 & 10.7 & 41.1 & 3.21 & 0.61 & 2.74 & 0.81 & 1.43 & 0.16 & 1.28 & 0.02 & 25.85 & 4.97 & 18.93 & 0.11 \\
\hline Pentland Squire & Tuberosum & 2 & 16.28 & 2.08 & 13.79 & 0.01 & 13.1 & 35.4 & 3.76 & 0.36 & 3.77 & 0.61 & 1.71 & 0.02 & 1.56 & 0.03 & 60.41 & 1.87 & 52.27 & 8.27 \\
\hline Record & Tuberosum & 2 & 12.17 & 1.12 & 11.64 & 0.02 & 4.1 & 7.6 & 4.27 & 0.20 & 4.01 & 0.85 & 1.51 & 0.13 & 1.56 & 0.06 & 51.77 & 2.33 & 46.40 & 2.49 \\
\hline Saxon & Tuberosum & 2 & 15.77 & 0.76 & 14.40 & 0.02 & 8.2 & 18.5 & 2.84 & 0.64 & 2.86 & 0.87 & 1.75 & 0.08 & 1.56 & 0.09 & 44.34 & 7.93 & 41.53 & 8.43 \\
\hline Scarborough & Tuberosum & 2 & 14.55 & 1.39 & 12.40 & 0.02 & 14.6 & 3.3 & 3.73 & 0.47 & 3.54 & 1.21 & 1.78 & 0.04 & 1.77 & 0.02 & 53.60 & 1.67 & 43.37 & 4.19 \\
\hline Stirling & Tuberosum & 2 & 16.67 & 4.09 & 15.10 & 0.01 & 5.9 & 29.2 & 3.89 & 0.35 & 3.60 & 0.22 & 1.95 & 0.19 & 1.73 & 0.13 & 63.46 & 10.09 & 54.22 & 3.42 \\
\hline Tay & Tuberosum & 2 & 12.54 & 1.58 & 11.54 & 0.02 & 6.4 & 25.8 & 3.76 & 0.37 & 3.45 & 0.83 & 1.63 & 0.09 & 1.31 & 0.48 & 46.51 & 1.33 & 39.89 & 5.24 \\
\hline Vales Everest & Tuberosum & 2 & 17.04 & 1.81 & 14.61 & 0.02 & 13.4 & 16.9 & 3.60 & 0.10 & 3.43 & 0.36 & 1.80 & 0.06 & 1.43 & 0.01 & 61.51 & 8.21 & 50.16 & 2.17 \\
\hline Wilja & Tuberosum & 2 & 16.27 & 3.27 & 14.20 & 0.02 & 11.4 & 12.9 & 3.08 & 0.50 & 3.34 & 2.14 & 1.70 & 0.26 & 1.66 & 0.05 & 48.54 & 1.91 & 45.39 & 9.01 \\
\hline \multirow[t]{3}{*}{${ }^{*}$ Mean +/- SE } & & 2 & 7.90 & 2.18 & 7.16 & 1.01 & 5.17 & 12.25 & 3.93 & 0.10 & 4.02 & 0.39 & 2.40 & 0.40 & 2.01 & 0.29 & 31.4 & 9.44 & 28.7 & 6.61 \\
\hline & Phureja & 7 & 8.04 & 0.77 & 7.28 & 0.59 & 7.17 & 4.61 & 3.51 & 0.15 & 3.22 & 0.16 & 1.59 & 0.10 & 1.46 & 0.07 & 28.2 & 3.57 & 23.6 & 2.74 \\
\hline & Tuberosum & 23 & 13.96 & 0.56 & 12.36 & 0.47 & 9.83 & 1.63 & 3.51 & 0.10 & 3.44 & 0.09 & 1.64 & 0.05 & 1.51 & 0.04 & 48.3 & 2.30 & 42.2 & 2.01 \\
\hline
\end{tabular}


Figure 1
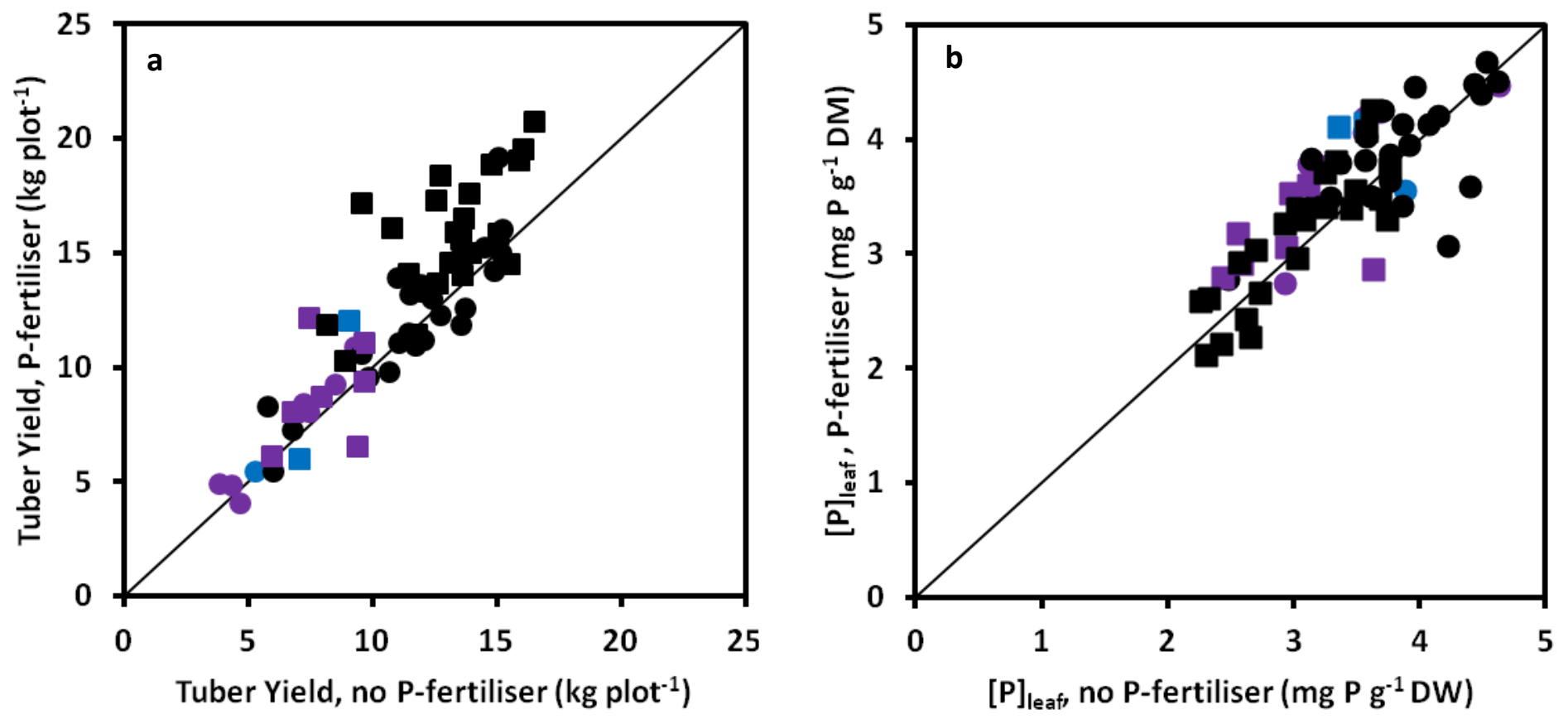
Figure 2
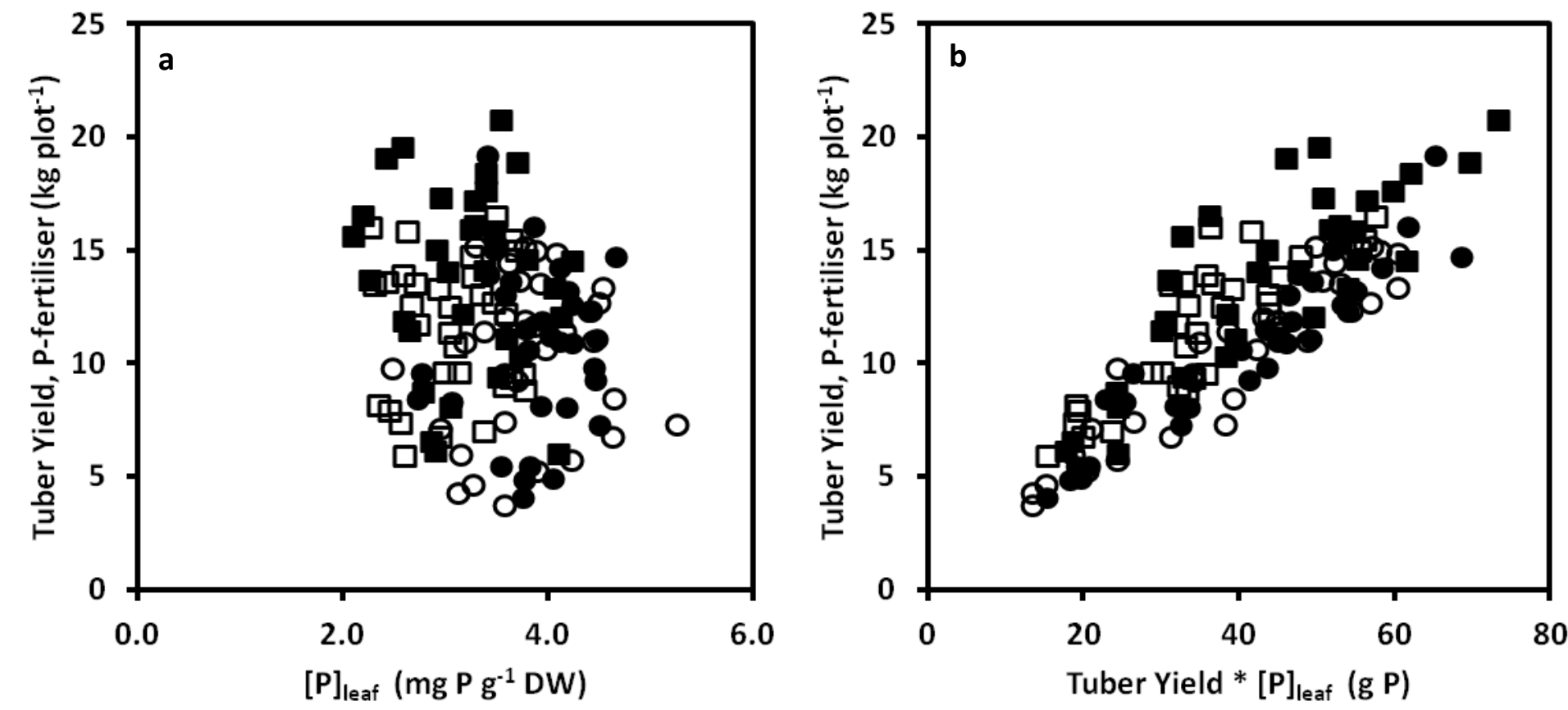
Figure 3

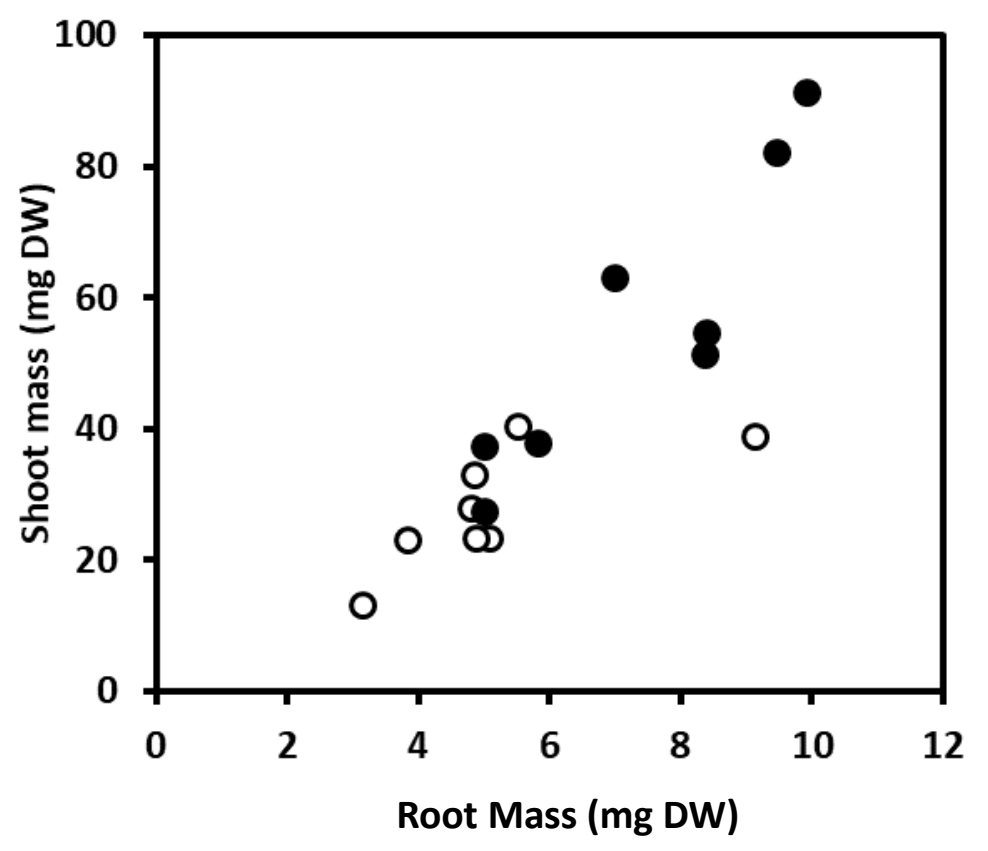


Figure 4

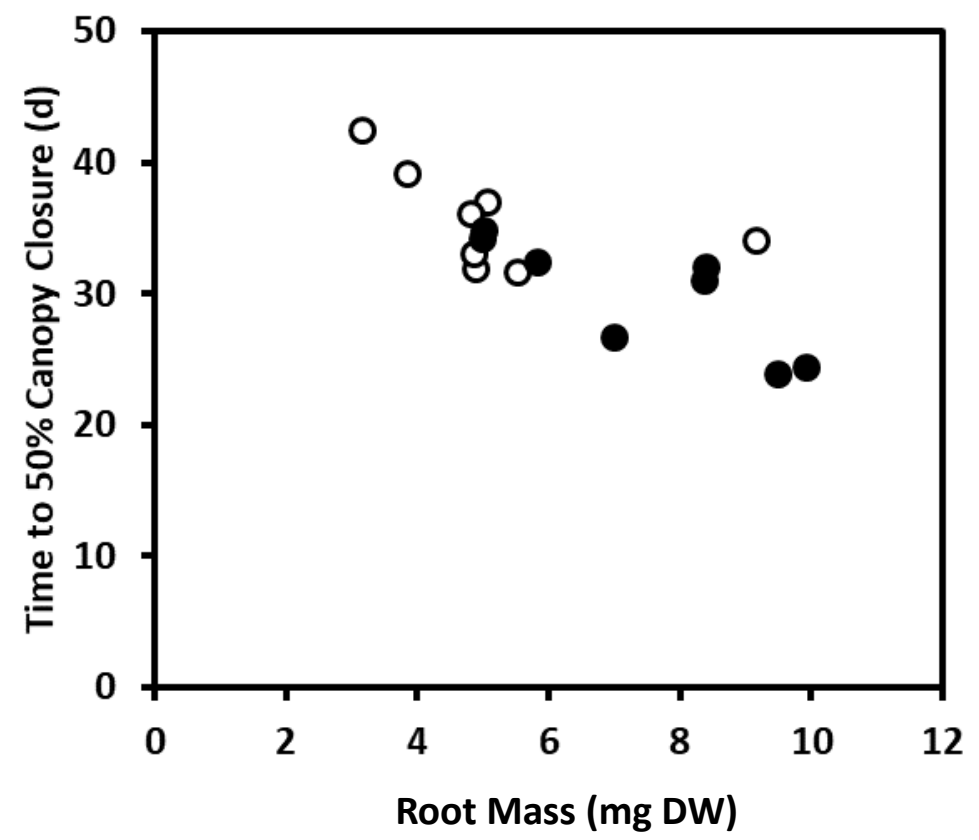


Figure 5

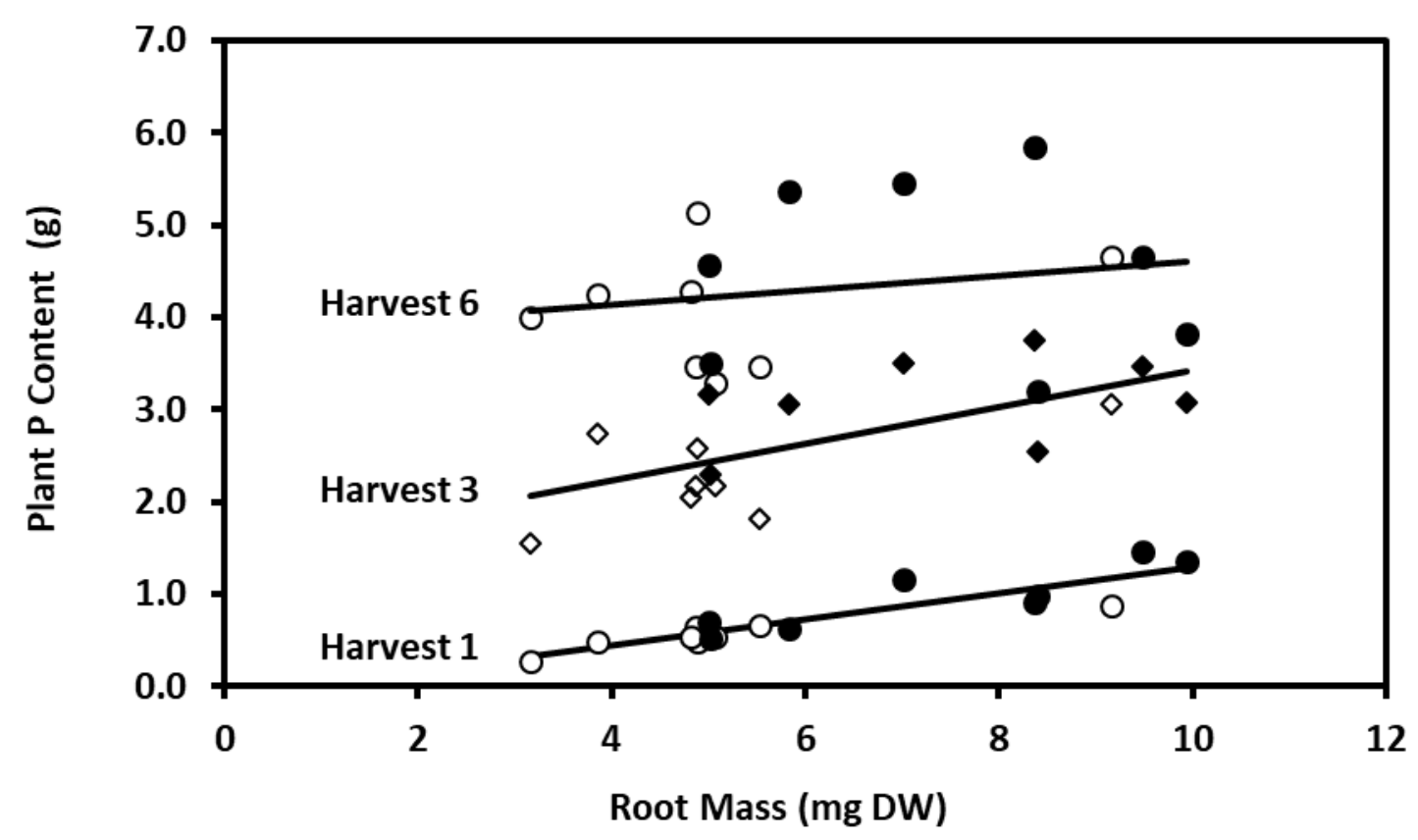


Figure 6
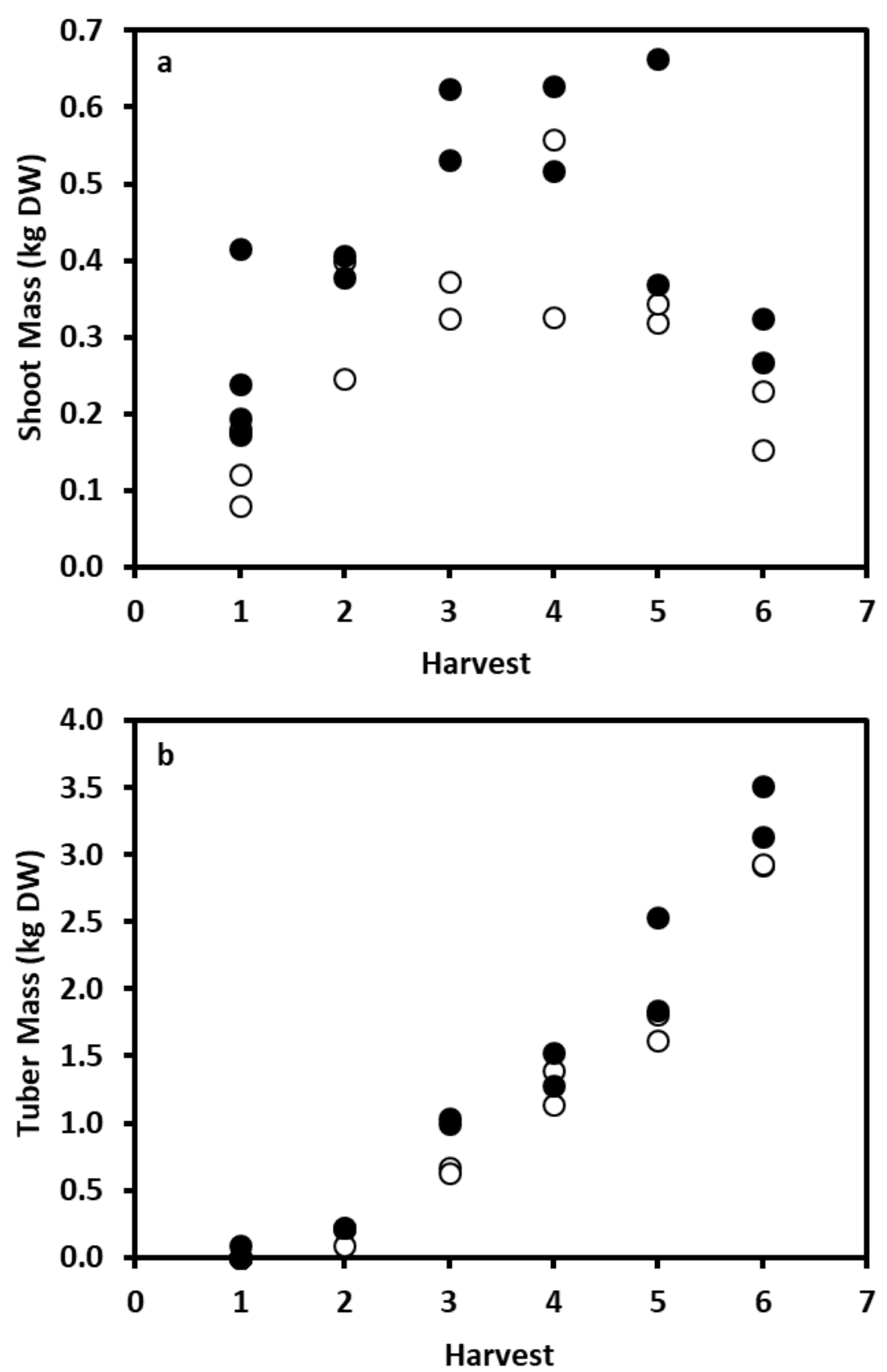
Figure 7

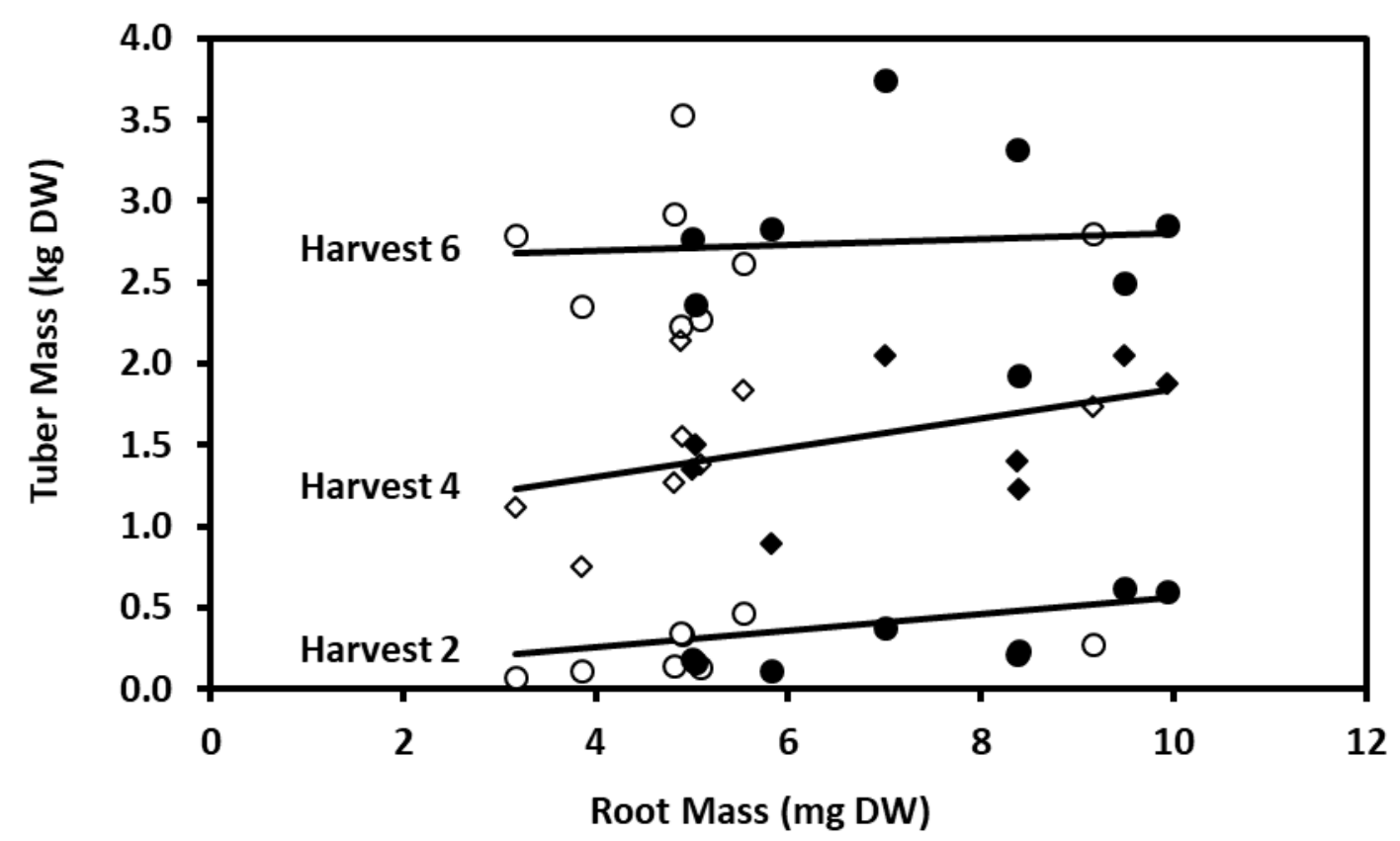


Figure 8
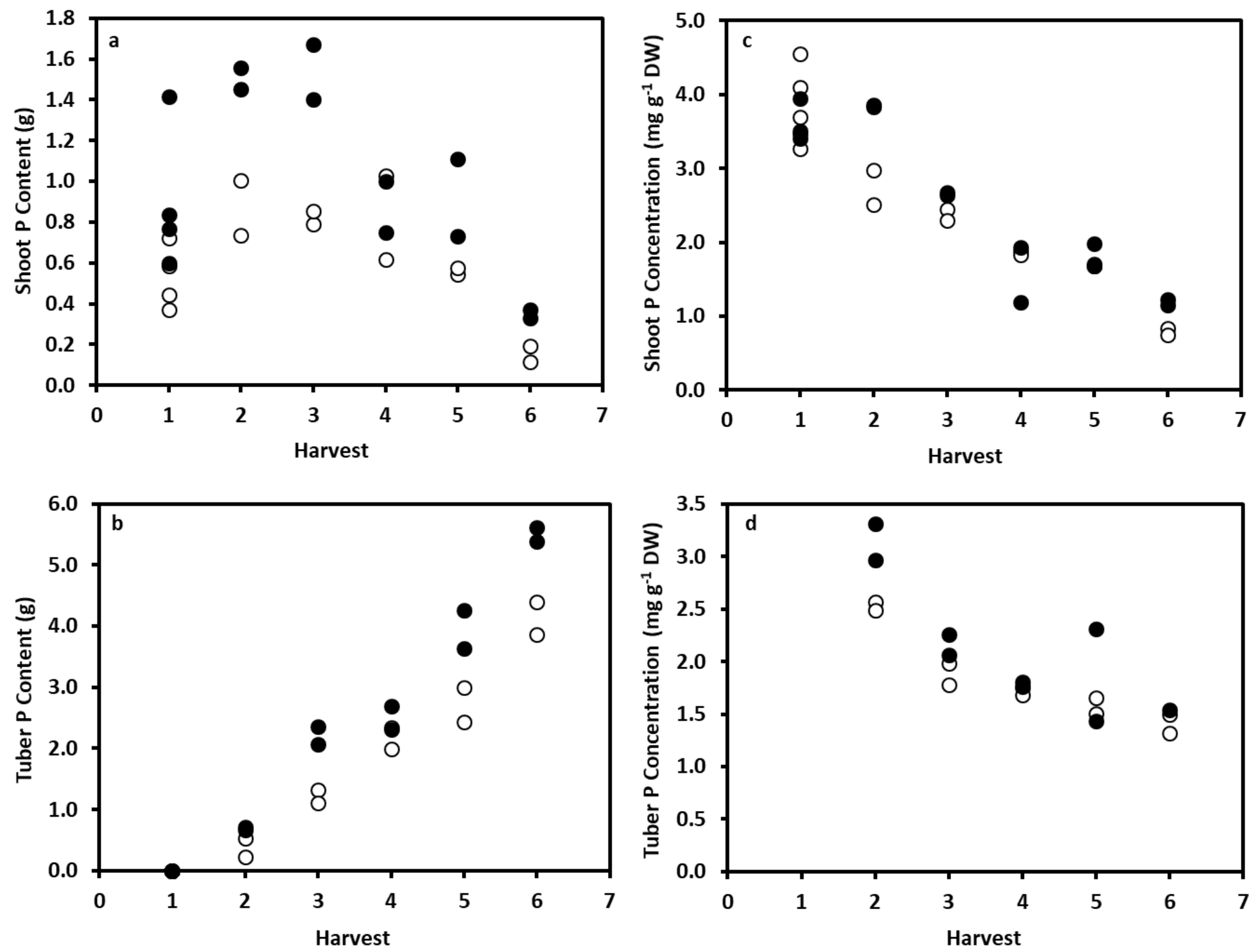
Figure 9
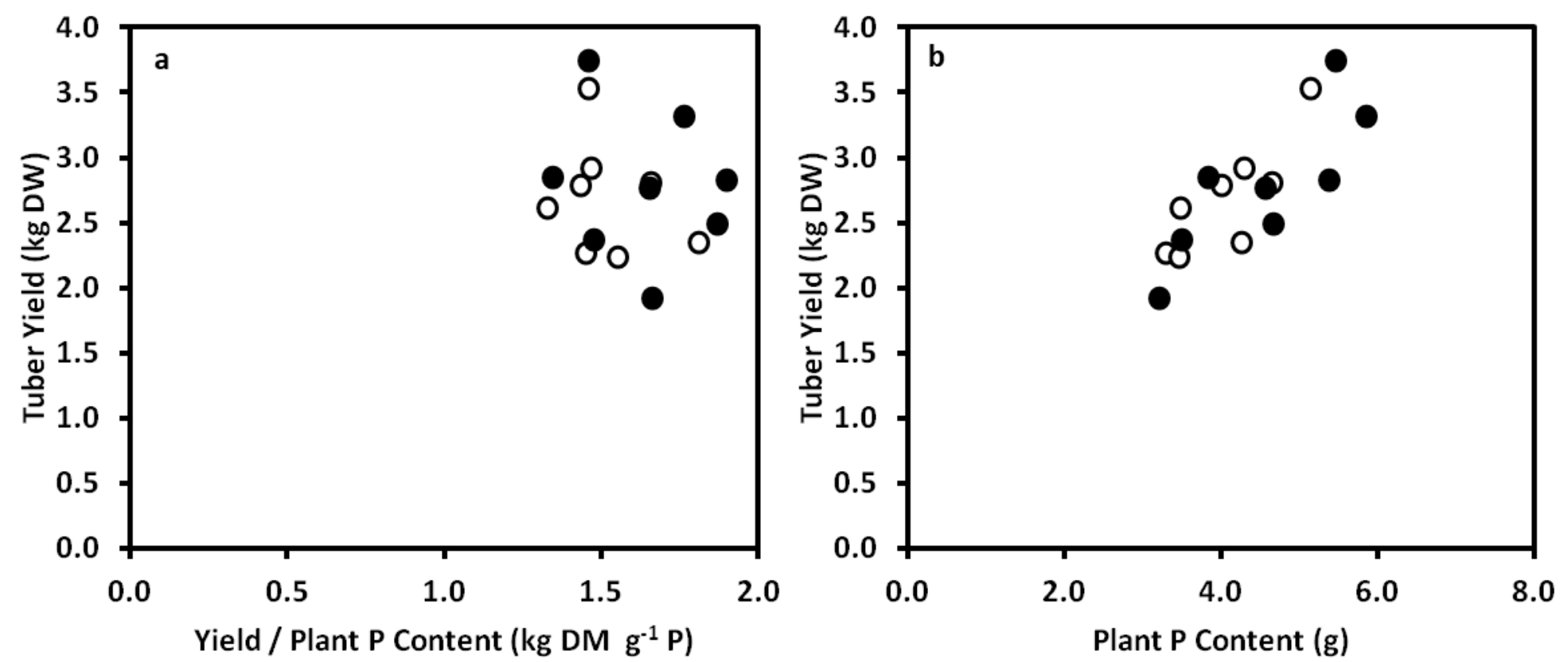